\title{
AZ ÖNKORMÁNYZATI FINANSZÍROZẢS LEHETSÉGES JÖVŐBELI IRÁNYAI
}

\author{
(Future Perpectives for Local Government Finance in Hungary)
}

\section{LADOS MIHÁLY}

\section{Bevezetés}

A tanulmány célja, hogy áttekintse azokat a forrásrendszereket, amelyek egyrészt segitik a hazai önkormányzatok pénzügyi önállóságának növelését, másrészt biztositják a kiegyenlitést is az eltérỏ jövedelem kapacitású önkormányzatok között. Az elsö cél az önkormányzati feladat- és forrásszabályozás kérdéskörébe tartozik, míg a kiegyenlítéssel csak részben foglalkozik az önkormányzati szabályozás. Ezek az eszközök döntően azok, amelyek a jelenlegi jövedelemtermelö képességben meglévö kủlönbségeket igyekeznek mérsékelni részben a források üjraelosztásán keresztül (pl. személyi jövedelemadó, kiegészító támogatás), részben a feladatok ellátásának hatékonyabb költséggazdálkodásával (pl. társulások ösztönzése). Az eszközök egy másik csoportja viszont a jövedelemtermelő kapacitás emelését szolgálja. Ez azonban a területi politika körébe tartozik, amelynek természetesen szintén fontos szereplói a helyi (megyei, települési) önkormányzatok.

A társadalmi-gazdasági átalakulás eltérő módon érintette az ország nagytérségeit. A kilencvenes évek eddigi időszakában a területi különbségek fokozódtak, de ez egy többirányú folyamat eređöjeként jött létre. A központi programoknak köszönhetően az infrastrukturális ellátottságban kiegyenlítỏdési folyamatokat tapasztalhatunk. Ugyanakkor a gazdaság átalakulásának nyertesei - döntően a külföldi töke aktivitásának köszönhetóen - elsősorban az ország hagyományosan fejlettebb terúletei: a föváros és agglomerációja, a (Északnyugat-) Dunántúl, valamint a nagyvárosok. Ez a jövedelemtermelő képesség - pl. személyi jövedelemadó, helyi adó potenciál - különbségeiben ragadható meg.

A területi kưlönbségek változását - erősődését vagy mérséklödését - đöntően befolyásolja az ország jövedelemteremtő képességének változása, a GDP várható növekedési üteme. Jelentősebb mérsékelés azonban csak egy erőteljesebb GDP növekedés mellett érhetö el. Ettöl függetlenül a területfejlesztés eszköz- és intézményrendszerét alkalmassá kell tenni mind a gazdaság modernizációjának elósegítésére, mind a területi kiegyenlitésre. Ezt a célirendszer szolgálja az 1996. tavaszán elfogadott területfejlesztési törvény, $s$ a törvény alapján létesủlö intézményrendszer (különbözö szintü területfejlesztési tanácsok), valamint az ahhoz rendelt központi és decentralizált forrásrendszer. Egyenlöre azonban csekély az összhang a területfejlesztést közvetlenül, illetve közvetve (ágazati fejlesztések) szolgáló alapok között. Mindkét fejlesztési támogatási kőr hozzáférhető az önkormányzatok, illetve azok térségfejlesztési társulásai számára is, azonban a saját forrásokat is igénylö támogatási rendszer általában a jobb jövedelmi pozícióval rendelkezö településeknek kedvez.

A rendszerváltás után az önkormányzati rendszer szabályozását a decentralizáció, mint átfogó törekvés motiválta. Ez a közszolgáltatások allokációját tekintve egy kettős folyamat. Egyrészt az önkormányzatiság kiépitésével megindult egy feladat 
decentralizáció a központi kormányzat és a helyi önkormányzatok között. Másrészt megkezdődött az állami szerepvállalás visszaszorítása azokon a területeken, ahol a piac és a magánvállalkozás hatékonyabban tud mükỏdni (ez a szélesebb értelemben vett privatizáció). Az államháztartási reform keretében - gazdasági egyensúly érdekében - a közösségi fogyasztás visszafogása és ennek részeként a központi költségvetés hiányának csökkentése a cél. Ez, mérséklődó elosztható forrást jelent, amivel arányosan csökkennek az állami - s ezen belül az önkormányzati - feladatok, amelyeket a szolgáltatások nem állami (piaci és non-profit) intézményei vesznek át.

\section{Normativ támogatás versus feladat finanszirozás}

1990 után tehát egy olyan önkormányzati intézményrendszer alakult ki, amelynek egyre szüküló pénzügyi feltételek mellett kellett ellátnia feladatait, azokat a feladatokat, amelyek tartalma nem volt kellöképpen definiálva, és az évek során is változott. A kedvezőtlen körülmények azonban nagy fokú intézményi ơnállósággal párosultak, és ez az ơnkormányzatok egy részénél lehetövé tette és egyúttal ki is kényszerítette, hogy egyre inkább javítsák mükődésuk hatékonyságát és növeljék a nem központi bevételeket.

Úgy tünik - legalábbis önkormányzati oldalról - konszenzus van abban, hogy az önkormányzati feladatok nincsenek világosan és egyértelmüen lefektetve a törvényben. Ennek oka nem jogi pontatlanság, hanem az, hogy nincsen politikai döntés abban a kérdésben, hogy mi az állam és az onkormányzatok feladata a közszolgáltatások különbözö területein. A piacgazdaságba való átmenet során csak fokozatosan alakul ki a feladatok és hatáskörök jól körülhatárolható felosztása (Hegedüs-Péteri 1996). Ha kialakult, akkor is kérdésként vetődik fôl, hogy az állam által felvállalt, de az önkormányzatok által ellátott feladatok (pl. közoktatás) esetében milyen mértékủ központi kormányzati támogatottság jelent elfogadható szintet. Kérdés az is, hogy ezt az elfogadható szintet biztosító támogatást milyen módon allokálják az önkormányzatok között. Ez lehetséges egy általános célú, de normatív alapú elosztási metódus alapján, de elképzelhetỏ meghatározott feladatmutatók és becsưlt kiadási szúkségletek meghatározott százalékú támogatása alapján is.

$\mathrm{Az}$ önkormányzati váltáskor létrehozott finanszírozási rendszer egyik legprogresszívebb eleme a kiadás-orientált tervezési metódusról a forrásszabályozásra történö áttérés. Ebben a rendszerben - tömegénél fogva kulcsszerepet játszanak a normatív támogatások. Ez a finanszírozási módszer eredendöen az önkormányzatoknak szánt kormányzati támogatások elosztási metódusaként múködik. Ez az elv viszont annál sérủlékenyebb, minél nagyobb számú kulcsot használnak ehhez a felosztáshoz. Nos, a hazai általános támogatás allokációjához már a nyitó évben (1990) több mint 10 elemböl álló rendszert alkalmaztak a költségvetési tervezők. Ezek száma lényegében megduplázódott 1995-ig. 1996-ban a normatíva jogcímek száma 14-re csökkent, azonban a közoktatás differenciált támogatási rendszere következtében összességében tơbb mint 200 a normatíva elemek száma. Ez 1997-re csökkent valamelyest, de számuk így is meghaladja a százat (Darázs 1996). Nem csoda, hogy az egyes normatívák lassan elvesztik a nekik szánt jelentéstartalmukat (az általános célú támogatás elosztását segítő kulcs), s egyre inkább az adott normativa megnevezésében 
meglévő feladat részleges finanszírozásaként kezelik. Ez pedig már eröteljes visszarendeződést indíthat el a kiadás-orientált tervezés felé.

A helyi támogatási rendszernek négy alapelvet kell követnie (Bird és Wallich 1992):

1. A támogatás hiánypótló szerepủ, hiszen az ónkormányzati bevételek soha nem képesek fedezni az összes kiadást. Tehát a támogatások a "pénzügyi lyukak betơmését" szolgálják.

2. A támogatás segítse a vertikális költségvetési egyensúly kialakulását. Az egyensúly hiánya a különbözỏ szintü onkormányzatok feladat struktúrájának eltéréséböl adódik, s ez a leggazdagabb önkormányzatokat is érinti.

3. A támogatásnak kezelnie kell az azonos helyzetủ telepủlések közötti különbségeket (horizontális költségvetési egyensúly).

4. A támogatásoknak osstönözniük kell a helyi költségvetési erôfeszitéseket, hogy a településeket saját forrásaik növelésére késztessék.

Szukséges tehát annak eldöntése, hogy a jövőben mely módszerek alapján múködjék az állam által felvállalt, de helyi ellátású feladatok, valamint az önként vállalt ơnkorinányzati feladatok állami finanszírozási részének az elosztása. Két nézet kristályosodott ki erőteljesebben a szakértők kőrében. Mindegyik lényegét tekintve a jelenlegi normativ rendszer - amelyben keverednek a kiegyenlítési és teljesítményfüggỏ normativák - fólszámolására tesz javaslatot.

Az egyik változat a becsült helyi kiadási szuikségletböl és a helyi bevételi kapacitásból, míg a másik az állami szerepvállalást is tartalmazó feladatok meghatározásából (közoktatás, szociális ellátás és segélyezés, egészségügy), s azok állami-helyi költségviselési arányaiból indul ki. Az első javaslat a kiadási szükséglet és a bevételi kapacitás különbözeteként meghatározott támogatási igénybe belesüríti a támogatás fentiekben felsorolt valamennyi jellemzőjét. A második modellben elválik egymástól a feladatorientált támogatás és az önkormányzatok közötti jelentős jövedelmi pozíció különbségeket tompító, kiegyenlitő támogatás. Megegyeznek abban is a változatok, hogy az évtized közepén egyre terebélyesedö ún. központosított elöirányzatoknak és az egyéb egyedi támogatási köröknek (színház, tủzoltóság, mükődésképtelenné vált helyi önkormányzatok) is az egységes támogatási rendszerbe szúkséges beépülnie. Mindkét irányzat a helyi bevételi kapacitás nơvelésére, s ezáltal a helyi ơnkormányzatok pénzügyi ơnállóságának növelésére helyezi a hangsúlyt.

Az önkormányzati pénzügyi önállóság növelése a forrásszabályozáson keresztül

\section{Az SZJA megosztás változása}

$\mathrm{Az}$ elmúlt évek forrásszabályozási vitái - kulönösen az állami költségvetés következö évi önkormányzati támogatási rendszer kialakításának időszakában gyakran az SZJA központi és helyi szint közötti megosztása kőrül csúcsosodtak. A magasabb ơnkormányzati részesedést szorgalmazók a helyi kormányzatok pénzügyi függetlenségének csorbulásaként, illetve emelkedéseként értékelték a megosztási arányok lefelé, illetve felfelé történö elmozdulását. 
Az 1988. évi adóreform egyik alappillére a közteherviselés általános kiterjesztését segítő magánszemélyek jövedelem adóztatásának bevezetése volt. Ezt az adótípust a kezdetektől, mint a helyi kormányzatok finanszírozását segítő bevételi típust képzelték el. A Parlament 1987 öszén azzal a feltétellel szavazta meg az SZJA általános bevezetését, hogy - a technikai lebonyolítás miatt szükséges kétéves csúszással - 1990-töl az SZJA teljes mértékben a tanácsok bevétele lesz, mégpedig úgy, hogy az egyes adófizetők által befizetett SZJA teljes összegét, az adófizető állandó lakhelye szerinti tanács számára utalja át az adó adminisztrációját végzó Adó- és Pénzügyi Ellenőrzési Hivatal (APEH).

Ennek hátterében az állt, hogy a nyolcvanas évtized első felében számos kísérlet történt a városi és községfejlesztési hozzájárulás (VKH) tanácsok közötti megosztására. Ez a munkavállalók lakcím szerinti nyilvántartása alapján akkor is lehetséges lett volna, azonban az akkori technológia mellett ez jelentős adminisztrációs terhet rótt volna a munkáltatókra. Így egyszerübb volt ezt a bevételt az adott cég székhely szerinti tanácsának befizetni. Így azonban ez a bevétel döntően városi bevételként müködött. Ugyanakkor erre az idôszakra esett egy eröteljes törekvés a községi tanácsi források megerősitésére, a községi és városi tanácsok bevételi lehetőségének kiegyenlítésére. Az SZJA bevezetésével ez megoldhatóvá vált, mivel az adót a központi adóhatóság részére kell befizetni, $s$ az adófizetők lakhely szerinti nyilvántartásával könnyen megoldható az adónak az adott tanácshoz történö eljuttatása.

Az eredeti szándékokat tükröző SZJA megosztási mechanizmus - az SZJA 100\%-ban a tanácsokhoz, illetve 1991-tỏl az önkormányzatokhoz történő visszajuttatása - csupán egyetlen évig, 1990-ben müködött. A lakosságszámra vetített SZJA bevételek között óriási differenciák mutatkoztak. Míg Tiszaújvárosban közel $15 \mathrm{E}$ Ft egy före jutó SZJA-val számolhattak, addig Gagyapátiban nem képződött adóköteles jövedelem. A legmagasabb és a leggyengébb adóbevételü települések között több mint 40-szeres különbség volt. A kilencvenes évek közepére ez a különbség jellemzöen már több, mint 100-szoros. A fajlagosan "leggazdagabb" település - kezdetben Tiszaújváros, majd 1993-tól Százhalombatta - egy före jutó adóbevétele napjainkra többnyire a vidéki átlag több mint háromszorosa. ${ }^{1}$ Ugyanakkor a települések közel 90\%-ának a fajlagos SZJA mutatója nem éri el a vidéki átlagot (1. táblázat).

Ilyen mértékủ jövedelem potenciálbeli különbségek mérséklése egy kiegyenlítő vagy a normatív támogatási rendszeren keresztül csak úgy volt lehetséges, ha az SZJA bevételeket megosztják a központi és a helyi kormányzati szint között, $\mathrm{s}$ a központban maradó hányadot kiegyenlítési célokra fordítják. Az átengedés mértéke többször változott: 1991-1992-ben 50\%, 1993-1994-ben 30\%, 1995-ben 30+5\%, 1996-ban $25+11 \%$, 1997-ben $22+16 \%$ és 1998-ban 20+20\%. A központban maradó rész nem jelent jövedelem-elvonást, hiszen egyre meghatározóbb mértékben az nyúit fedezetet a normatív támogatások biztositásához (2. táblázat). 
Tér és Társadalom, 12. 1998. 1-2. 59-86. p.

\section{TÁBLÁZAT}

Az egy före jutó SZJA potenciál különbségei, 1988-1996

(Personal Income Tax Potential per Capita, 1988-1996)

\begin{tabular}{|l|r|r|r|r|r|r|r|r|r|}
\hline & 1988 & 1989 & 1990 & 1991 & 1992 & 1993 & 1994 & 1995 & 1996 \\
\hline $\begin{array}{l}\text { Legmagasabb fajlagos } \\
\text { SZJA befize-téssel } \\
\text { rendelkezó telepulés } \\
\text { (E Ft/fo) }\end{array}$ & 14,9 & 20,8 & 26,6 & 37,8 & 41,7 & 58,8 & 67,8 & 87,4 & 113,7 \\
\hline Budapest (E Ft/fo) & 12,6 & 17,1 & 22,0 & 29,1 & 36,6 & 43,9 & 50,6 & 63,0 & 78,7 \\
\hline Vidék átlaga (E Ft/fó) & 5,3 & 7,0 & 9,6 & 12,4 & 15,5 & 19,0 & 21,4 & 27,6 & 34,9 \\
\hline $\begin{array}{l}\text { Legmagasabb } \\
\text { érték/vidéki átlag }\end{array}$ & $\begin{array}{c}2,8- \\
\text { szoros }\end{array}$ & $\begin{array}{c}\text { s,0- } \\
\text { szoros }\end{array}$ & $\begin{array}{c}2,8- \\
\text { szoros }\end{array}$ & $\begin{array}{c}3,0- \\
\text { szoros }\end{array}$ & $\begin{array}{c}2,7- \\
\text { szeres }\end{array}$ & $\begin{array}{c}3,1- \\
\text { szeres }\end{array}$ & $\begin{array}{c}3,2- \\
\text { szeres }\end{array}$ & $\begin{array}{c}3,2- \\
\text { szeres }\end{array}$ & $\begin{array}{c}3,3- \\
\text { szoros }\end{array}$ \\
\hline $\begin{array}{l}\text { l.000 Ft/fó SZJA alatti } \\
\text { telepúlések száma }\end{array}$ & 65 & 32 & 11 & 8 & 7 & 3 & 4 & 3 & 1 \\
\hline $\begin{array}{l}\text { 10.000 Ft/fó SZJA } \\
\text { alatti telepúlések száma }\end{array}$ & 3.066 & 3.013 & 2.848 & 2.539 & 2.026 & 1.417 & 1.205 & 711 & 396 \\
\hline $\begin{array}{l}\text { Vidéki átlag alatti } \\
\text { telepúlések száma }\end{array}$ & 2.755 & 2.792 & 2.804 & 2.810 & 2.844 & 2.849 & 2.863 & 2.799 & 2.808 \\
\hline $\begin{array}{l}\text { Vidéki átlag alatti } \\
\text { telepulések aránya (\%) }\end{array}$ & 89,4 & 90,5 & 90,7 & 91,0 & 90,7 & 90,9 & 91,0 & 89,5 & 89,7 \\
\hline
\end{tabular}

Forrás: PM adatkőzlés alapján saját számítás

Míg 1991-ben a központosított SZJA a normatív támogatás alig egyharmadát fedezte, napjainkra ez az arány $80 \%$ fölé növekedett. Az 1998. évi költségvetési törvényjavaslatban szereplő adatok alapján 1998-ban a központban maradó SZJA már teljes egészében fedezetet nyújt a normatív állami hozzájárulásokhoz. Söt mintegy 5 Mrd Ft-tal meg is haladja azt. Ez nem kicsi összeg, ha figyelembe vesszük azt, hogy lényegében 1997-ben ennyit szánt a kormányzat a decentralizált területfejlesztési alapon belưl az önkormányzatok által pályázható területi kiegyenlítésre.

\section{TẢBLÁZAT}

A normatív támogatások SZJA fedezete, 1991-1998

(Personal Income Funds for Normative Grants 1991-1998)

\begin{tabular}{|l|c|c|c|c|c|c|c|c|}
\hline & 1991 & 1992 & 1993 & 1994 & 1995 & 1996 & $1997^{*}$ & $1998^{*}$ \\
\hline $\begin{array}{l}\text { Normatív állami } \\
\text { hozzájárulás (Mrd Ft) }\end{array}$ & 148,5 & 169,8 & 207,5 & 210,6 & 232,7 & 231,7 & 260,2 & 275,4 \\
\hline $\begin{array}{l}\text { SZJA kózponti része } \\
\text { (Mrd Ft) }\end{array}$ & 47,0 & 63,0 & 120,0 & 148,8 & 173,9 & 180,1 & 221,4 & 280,5 \\
\hline $\begin{array}{l}\text { SZJA-ból fedezett } \\
\text { normatív támogatás (\%) }\end{array}$ & 31,6 & 37,1 & 57,8 & 70,7 & 74,7 & 77,7 & 85,1 & 101,9 \\
\hline
\end{tabular}

* 1997 tervezett, 1998 költségvetési törvényjavaslat

Forrás: TẢKISZ adatbázis alapján saját számitás

A táblázatban bemutatott SZJA fedezeti hányad 1995-tỏl még magasabb arányú lenne, ha a kiegyenlítő támogatásokat nem sorolnák hol a normatívák közé, hol a helyben maradó SZJA tételek közé. Politikailag jól hangzik az önkormányzatok egy 
része felé a látszólagosan megnövelt helyi SZJA részesedés. Ugyanakkor az 1995-1998-as periódusban $+5,+11,+16$ és +18\%-os helyben maradó SZJA-részeket szerencsésebb lenne a normatív támogatási blokkban vagy önálló kiegyenlitő támogatási blokkban szerepeltetni. Az elöbbi mellett - a normatív támogatási rendszer esetleges hosszabb távon való fơnnmaradása esetén - az az érv szól, hogy a központban maradó SZJA hányad ma teljes egészében a normatív támogatások forrását képezi. Az utóbbi mellett pedig a kiegyenlítési támogatások egyszerüsítésének, egységesítésének lehetőségével lehet érvelni. Ez azt is feltételezi, hogy a maradék kiegyenlítési típusú elemeket is - települési igazgatási, kommunális és sportfeladatok, kőzmüvelödési feladatok - ki kell emelni a normatívák közül.

Esetenként elhangzik, hogy kisebb lenne a finanszírozási feszültség, ha az önkormányzatok nem két év csúszással jutnának hozzá az SZJA bevételekhez. A különböző hatások (adókulcsok, adósávok, kedvezmények, mentességek, infláció) eredöjeként a kilencvenes évek elsö felében évente 40-50 Mrd Ft-tal emelkedtek az SZJA-ból származó bevételek, egy átállás a kétéves csúszással fölhasznált forrásról, a folyó adóbefizetésekhez igazodó rendszerre egy kb. 100 Mrd Ft-nyi SZJA pluszforrást eredményezne. A nyereség a mai helyzetben látszólagos, hiszen a két évvel ezelöstti SZJA havonkénti egyenlö összegben történö folyósitása nyilván a folyó SZJA elölegekből történik. İgy a becsült folyó SZJA befizetéshez igazított forrás-folyósítás plusz igényként jelenik meg adott évben az államháztartáson belül. Ez a plusz igény csak a deficit növelésével, mintegy $100 \mathrm{Mrd}$ Ft-nyi államkölcsön fölvételével lehetne biztosítani. Ez egyrészt felboritaná az államháztartási hiány szintjére vonatkozó elvárásokat, másrészt egy jelentös tétellel növelné az adósságállományt. Az átállás az adminisztrációs eljárást is bonyolultabbá tenné, mivel új feladatként jelentkezne az utalások utólagos elszámolása (tervezett bevétel szerinti folyósítás - tényleges bevétel szerinti elszámolás).

Összegezve a személyi jövedelmek megosztott jövedelemként való további fơnntartásának lehetőségét, a következő megállapításokat tehetjük:

$\Rightarrow$ A megosztott SZJA hosszú távon az önkormányzatok stabil jövedelemforrása lehet, amely a kétéves technikai csúszás következtében ismertté váló forrásmennyiség miatt jól tervezhetö. A jelenlegi trendek mellett a központban maradó SZJA fogja teljes mértékben fedezni, mind a normatív támogatásokat, mind az SZJA kiegyenlitö támogatásokat.

$\Rightarrow$ A tervezhetőséget tovább erősítené, ha egyrészt maga az SZJA rendszere (adókulcsok, adósávok, mentességek, stb.) stabilabb lenne, másrészt, ha a megosztási arányok hosszabb időszakot átfogva változatlanok lennének, vagy ha egy-egy négyéves ciklusra kialakulna az évenkénti változás menetrendje.

$\Rightarrow$ Nem szerencsés összemosni a tisztán helyben maradó SZJA-t és a "faladatokkal terhelt" SZJA-t. Az utóbbiakat vagy egységesen a normativ támogatási, vagy egy egységes és egyszerüsített kiegyenlítési rendszerbe szükséges beépíteni.

$\Rightarrow$ A megosztott SZJA rendszerében a helyi önkormányzatok passzív bevételi érdekeltségüek. Részesedésük ebböl a forrásból a megosztási kulcs változásában, illetve a központi SZJA-ból finanszírozott normatíva és kiegyenlítő támogatási elemek kulcsainál elért pozícióktól függenek. Aktív gazdaságfejlesztő tevékenység esetén azonban a munkanélkủliek munkával történö lekötése többlet SZJA forrást hozhat, illetve azzal párhuzamosan csökkenhet a szociális ellátás (segélyek) területén jelentkező nyomás. 
Tér és Társadalom, 12. 1998. 1-2. 59-86. p.

\section{Pótadózási rendszerek}

A következőkben három metszetben tekintjük át a pótadó alkalmazásának lehetőségeit a hazai önkormányzati finanszírozási rendszerben. Az első metszet a hazai történeti hagyományokat mutatja be; a második metszet nemzetközi kitekintést biztosít a témakörbe; a harmadik pedig összegzi néhány szakértői csoport SZJA pótadóztatási javaslatát.

\section{Magyarországi hagyományok}

A tanácsrendszer bevezetéséig a központi adók pótadóztatása fontos eleme volt az önkormányzati gazdálkodásnak. A kiegyezés időszakában, azokat az adókat, amelyeket a város bevételeiböl nem tudott fedezni, a városi adóból kellett kifizetni. A városi adót a királyi egyenes adók után vetették ki annyi százalékban, hogy a fedezetlen kiadásokra elég legyen (Bükki 1991). 1870-töl annyiban változott a helyzet, hogy az adóbevételek voltak a kiadások fedezeti alapjai és az egyéb bevételek a kiegészitök. A városi adó kulcsát a költségelőirányzattal együtt állapitották meg, a belügyminisztérium azzal együtt hagyta jóvá. Az adóbevétel tényleges nagyságát befolyásolhatta a központi adó alapja és kulcsa, a pótadó kulcsa, valamint a beszedési hatékonyság. Az adó behajtása az önkormányzat feladata volt, amelynek hatékonysága a jelzett időszakban meglehetösen gyenge volt. (3. táblázat)

\section{TÁBLÁZAT}

A városi adó bevételek és hátralékai Gyỏrben, 1873-1876

(Tax Revenues and Overdues in City of Györ 1873-1876)

\begin{tabular}{|l|r|r|r|r|}
\hline & \multicolumn{1}{|c|}{1873} & \multicolumn{1}{|c|}{1874} & \multicolumn{1}{c|}{1875} & \multicolumn{1}{c|}{1876} \\
\hline Városi adó kulcsa (\%) & 55 & 75 & 60 & 50 \\
\hline Jóváhagyott városi adó összege (Ft) & 94.000 & 131.200 & 105.000 & 94.000 \\
\hline $\begin{array}{l}\text { Év végén felgyült hátraléki } \\
\text { követelések összege (Ft) }\end{array}$ & 113.600 & 74.000 & 83.000 & 88.000 \\
\hline Az év végi adóhátralék aránya (\%) & 120 & 56 & 79 & 93 \\
\hline
\end{tabular}

Forrás: Bükki (1991) 1-2. táblázat alapján

A két világháború kỏzött a telepưlések bevételeinek túlnyomó részét az állam által átengedett adók, a helyi adók, a helyhatósági díjak és járulékok képezték. Amennyiben a községi, városi költségvetés kiadásainak fedezetéül a fenti bevételek nem voltak elegendők, akkor a szükséghez képest, de legfeljebb 50\%-ig (a vármegyék esetében $30 \%$-ig) községi pótadó volt kivethetỏ az állami egyenes adók (föld-, ház-, tantiem- és társulati adó) összevont összege alapján. Generális szabályként érvényesưlt, hogy az állami és helyi pótadók összege nem haladhatta meg az adózó összes jövedelmeinek 75\%-át. A társuló községek közös kiadásai az illetỏ községeket a pótlékolható állami egyenesadókból és az általános kereseti adóból befolyt összegek aránya szerint, vagy a községek teherbírása szerint terhelték. Arra, hogy a pótadó kulcsa ne haladja meg a megengedett maximumot, a királyi adófelügyelö, illetve a belügyminiszter felügyelt. Elöírás volt, hogy a költségvetést jóváhagyás végett be kellett nyújtani az említett szervekhez. (Páll 1991) 
Az 1920-as évek második felében az állam több apróbb változtatással mérsékelte az önkormányzati bevételeket. Ezek sorába tartozott az egyenes adók egyes tételeinek csökkentése, amellyel a községi pótadó összege is automatikusan csökkent. Jellemző volt ebben az időszakban az is, hogy az állam terheinek egy részét - fedezet átadás nélkül - igyekezett áthárítani az önkormányzatokra. Ezek külön-külön nem jelentettek volna nagy terhet, együttes összegük azonban az 1920as évek végére már elérte az önkormányzatok éves kiadásainak 7,5\%-át anélkül, hogy ez az önkormányzatot többletkiadásként terhelö összeg növelte volna a hozzá kapcsolódó szolgáltatások mennyiségét vagy színvonalát. Lényegében az állam önmagát tehermentesítve az önkormányzatokat korlátozta saját bevételei feletti szabad rendelkezésükben. (Éberth 1931)

Az önkormányzatiság hivei vitatták a kialakult rendszert. Egyetértettek azzal az alapelvvel, hogy az állam és a község (város) az adók mértékét a jövöben is a polgárok adóviselö képességének figyelembevételével állapítsák meg, de szorgalmazták, hogy az önkormányzati szükségletek természete - és azoknak az egyének jólétére gyakorolt hatása - miatt a községekben (városokban) nagyobb tere legyen az érdekeltségre alapozott adózásnak.

Felvetették, hogy a községi pótadó rendszer és az egyenes adókból való részesedés nem csak nem elégítik ki a községek (városok) szulkségleteit, de függővé is teszi a bevételek jelentös hányadát az állami adók rendszerétöl. Érveik között szerepelt az is, hogy az alkalmazott rendszer a községek (városok) lakosaiban elhomályositja azt a tudatot, hogy a saját közuilete fönntartásához önmaguknak is külön anyagilag hozzá kell járulniuk. Az önálló közszolgáltatás hivei azt vallották, hogy az önkormányzatok bevételei elsősorban az érdekeltség szolgáltatásából, valamint az önálló alapokra helyezett városi adókból és illetékekböl táplálkozzanak. A következő alapelveket fogalmazták meg (Éberth 1991):

- szabadabb mozgást az önkormányzatokban,

- a városi adók önálló alapokra helyezését,

- a községi pótadó jelentőségének leszorítását.

A világgazdasági válság azonban a folyó vitákat megszakitotta és ezeket a törekvéseket egy időre levette a napirendről.

Összegezve a hazai pótadóztatás elözményeit a következő megállapításokat tehetjük (Lados 1997):

- a pótadót jellemzően a helyi költségvetés egyensúlya érdekében központi adók feluulrỏl behatárolt százalékában vethette ki a helyi önkormányzat, ha egyéb rendszeres jövedelmei az önkormányzat által ellátott közszolgáltatások költségeit nem fedezte,

- a pótadó alapjaként egyenes adók, általában vagyoni-, illetve vállalati jövedelemadók szolgáltak,

- az adott évre alkalmazandó pótadó kulcsát, az önkormányzat költségvetésével egyetemben - a kormányzati szervek (belügyminisztérium) hagyták jóvá,

- mind a pótadóval terhelhetoo, mind az állam és az önkormányzat között megosztott adókat a helyi adóapparátus adminisztrálta,

- az önkormányzatok a pótadó szerepének mérséklését szorgalmazták, mivel annak alkalmazása rendkívul érzékeny volt a központi adóalapok és adókulcsok változására - inkább az önálló alapú helyi adók bevezetését szorgalmazták. 
Következtetések a pótadóztatás bevezetéséhez a hazai hagyományok alapján:

1. A korábban alkalmazott adóalapok közül a központi földadó 1995-ben megszünt, s a mükődö vagyoni típusú adók mindegyike helyi adó. A tantiemadó (lényegében osztalékadó) és a társulati adó (lényegében vállalati jövedelemadó) pótadója ma csak az önkormányzatok egy része számára biztosítana forrásokat, mivel a települések döntỏ hányadában kevés az adóztatható vállalkozás. Az adóirodalom szerint a vállalkozások helyi adóztatása torzítja azok versenyképességét ezért azok alkalmazása kevéssé kivánatos. Ugyanakkor az iparüzési adó fölfogható az ÁFA pótadójaként is. A központi adók közül ma csupán az SZJA pótadóztatása képes forrásokat biztositani minden önkormányzat számára.

2. Ma a kőzponti adókat - gépjármủadó kivételével - a központi adóhatóság (APEH) adminisztrálja Magyarországon. Ezért, ma - az említett kivételtől eltekintve - bármely központi adó pótadóztatásának adminisztrációját is célszerü az APEH-hoz telepíteni.

3. Bármely alapú pótadó bevezetése feltételezi, hogy az összadóteher nem változik. Így a pótadó bevezetése csak a központi kulcsok megfelelö mértékủ csőkkentésével megvalósitható.

\section{Nemzetközi kitekintés}

A pótadóztatás nemzetközi rendszere ugyanazt az elvet követi, amelyet a Magyarországon alkalmazott rendszer is a II. világháború elött, mely szerint a pótadó szerepe a helyi költségvetés forrásoldalának a kiegészítése a kiadási szulksségletek szintjéig. A pótadó alapját tekintve azonban már jelentỏs eltérés mutatkozik a korábbi hazai és a jelenlegi nemzetközi gyakorlat között. A magyar rendszer a vagyoni típusú adókat és a vállalati jövedelemadót pótadóztatta. Ezek mindegyike egyenes adó volt. A mai nemzetközi gyakorlat jellemzöen az SZJA-t pótadóztatja. Ez azt jelenti, hogy a két rendszer nem csupán az eltérỏ adóalap alkalmazásában kủlönbőzik, hanem abban is, hogy a pótadótatásra kiválasztott adó az országok tơbbségében sávos, rendszerint progresszív adó. Igaz a pótadó esetében ez nem feltétlenül jelent sávos adókulcsokat.

A helyi önkormányzati pótadoknak alapvetően két típusa lehet:

- a kőzponti adókulcs egységes megnövelése, vagy

- egységes százalékos formában kifejezett pótadó, amit minden sáv adókulcsa esetében kivetnek.

Az elsö módszert például az északi országok alkalmazzák, míg a másodikat Svájc. Svédországban országosan az induló-kulcs nulla, így a legalacsonyabb sávba esők kizárólag a helyi pótadót fizetik, ami a nettó adóalap 30\%-ig terjedhet. A központi kormány csak a magasabb sávokban adóztatja a jövedelmeket. A jelzett maximális pótadó kulcs azonban három elemböl tevődik össze, mivel minden önkormányzati szint kivetheti a pótadót a jövedelemadóra. Mindegyik szint behatárolt keretek közőtt mozoghat az adókulcsot tekintve. A telepulési önkormányzatok játéktere a legnagyobb, a pótadó kulcsát jellemzően 14-20\% között állapítják meg. A megyei önkormányzatok 8-12\%-os sávban mozoghatnak, míg a legkisebb önkormányzati egységek az ún. paris-ok (egyházkőzségek) maximum 2\%-ig mehetnek el. Így összesen a fizetett adó az országossal együtt négy kulcsból tevődik össze. 
A többszörös adó miatt megnő a munkáltatók és az adóhatóságok adminisztratív terhelése.

A második módszer az egyes adósávokban alkalmazott kulcsok egységes százalékában határozza meg a pótadó kulcsát. Vagyis a pótadó kulcsok a központi adóhoz hasonló progresszivitást mutatnak. Ez azt jelenti, hogy ha az önkormányzatok összessége ugyanazt a pótadó kulcsot választja, akkor az adóbevétel területi különbségei fokozódnának.

Összegezve a személyi jövedelmek pótadóztatásának nemzetkőzi tapasztalatait, a következő megállapításokat tehetjük:

- a személyi jövedelmekre alkalmazott pótadó rendszerek mindegyike a központi jỏvedelemadó sávjaihoz igazodva állapítja meg a pótadó kulcsát, amelyet minden sávra egységesen alkalmaznak

- A skandináv modellben egy felső limitet beépítve minden adósávban ugyanakkora kulccsal növelik a központi adó kulcsát, míg a svájci modellben minden adósávban a megfelelö adókulcs azonos százalékába határozzák meg a pótadó kulcsát

- a skandináv modell valamennyi önkormányzati szint számára lehetỏvé teszi a személyi jövedelmek pótadóztatását

Következtetések a személyi jövedelmek pótadóztatásának hazai bevezetéséhez a nemzetközi tapasztalatok alapján:

- Valamennyi önkormányzat számára biztosíthat jövedelmet.

- Lehetőséget ad a helyi döntésủ források bövítésére.

- Különbözö típusú (települési, megyei esetleg kisebbségi) önkormányzatok számára is elérhetóvé válhat az önálló adóforrások képzése.

- Egy felsó limit beépítésével ez a pótadó nem torzítja jelentősen a helyi gazdaság versenyképességét.

- Bármilyen formában történik az SZJA pótadóztatása, tartósan szükség lesz az SZJA kiegészítésre, hiszen a pótadóztatás csak kisebb mértékben változtat az SZJA területi eloszlásán. Az SZJA pótadóztatásakor nem is ezen van a hangsúly, hanem a helyi döntésü adókulcsok alkalmazásával, a helyi önkormányzatok pénzügyi önállóságának fokozásán.

A pótadóztatás szakértői javaslatainak áttekintése

Az SZJA megosztás szinte évenkénti változása kiszolgáltatottá teszi a helyi önkormányzatokat és már az indulásnál ellehetetleníti - az államháztartási törvényben (Áht) elöirt - tőbb évre szóló pénzügyi tervezést. Éppen ezért már a kilencvenes évek első harmadától készültek olyan külfơldi és hazai szakértöi javaslatok és modellezések, amelyek a megosztott SZJA rendszerét az SZJA pótadóztatásával váltanák ki. Ezek közül csupán azokat ismertetjük vázlatosan, amelyek nem csupán az SZJA pótadóztatásának előnyeit és hátrányai taglalják, hanem igyekeznek modellezni is a változás hatásait.

Világbanki szakértôi jovaslat ${ }^{2}$

Bird és Wallich javaslataiban a saját döntésü források növelésére és a támogatási rendszer átalakitására helyezte a hangsúlyt a hazai önkormányzatok finanszírozási rendszerének fejlesztése esetében. $\mathrm{Az}$ általuk leírt rendszerben nem az 
önkormányzat igazodik a központilag elosztott támogatásokhoz, hanem a támogatási rendszer a becsült kiadási szükséglet és a helyi bevételi kapacitás különbözeteként adódik. A tớmogatás-egyszerüsités azt jelenti, hogy a jelenlegi részletező kapacitásnormák helyett inkább a "fogyasztókhoz" kell kötni a támogatásokat. A bevételi kapacitásokat figyelembe vevő támogatási rendszer arra épül, hogy a központi költségvetési támogatásoknak $(T)$ a becsült kiadási szükségletek $(\mathrm{K})$ és a helyi bevételi kapacitás (B) különbségeként kell adódnia ( $\mathrm{T}=\mathrm{K}-\mathrm{B}$ ).

Ezen logika szerint, ha az átlagos kiadási szükségletek számítása normatívan, a fogyasztói igényeket követö mutatók (népességszám, korcsoport, stb.) alapján történik, akkor a becsült költségvetési kapacitásnál nagyobb bevétel nem csökkenti az állami támogatást. Ugyanakkor a feltételezett bevételeket a számított szintig az önkormányzatoknak be is kell szednie, hiszen az átlag alatti költségvetési "erőfeszítéshez" nem jár központi költségvetési támogatás.

Ennek a modellnek a bevezetése azon múlik, hogy valóban jelentős mértékủ helyi bevétellel rendelkeznek-e az önkormányzatok. Vizsgálatuk időszakában (1991) ez nem volt jellemzö, ezért javasolták az SZJA helyi pótadóztatásának bevezetését. Ez véleményük szerint nem járna a lakossági adóterhek növekedésével, mert a helyileg engedélyezett adókulcsok mértékétöl függően csőkkenne a központi adókulcs. Így tulajdonképpen csak az SZJA megosztási elve változna meg: nem utólagosan történne meg a forrásmegosztás, hanem helyi döntésen múlna, hogy az alacsonyabb szintü adókulcsot mennyivel "fejeli meg" az önkormányzat.

A fentiek figyelembe vételével a szerzők egy alternatív lehetöségként a következő önkormányzati finanszírozási felépitést javasoltak:

- a központi SZJA pótadóztatása,

- normativ támogatás, kiegészítve a kiegyenlítő SZJA támogatással (az egyszerüsített támogatási elosztási képlet alapján, mely magában foglalja a bevételi kapacitást),

- megnövelt helyi adó és díj kapacitás,

- egyéb kiegészítő támogatások.

A javasolt modellben - az akkori SZJA megosztási arányokat figyelembe véve - a központi adókulcsok 50\%-os mérséklése szükséges. A központi SZJA teljes mértékben a normatív támogatás alapját képezné, amely magában foglalná a kiegészitő SZJA támogatást is. Ha az önkormányzat egy $100 \%$-os egyenes pótadót vet ki az országos adóra, akkor ténylegesen a korábbi $50 \%$-os SZJA részt gyüjtené be a pótadóból ahelyett, hogy megosztott bevételként kapná meg. A támogatás kalkulációnál ezt a pótadó kulcsot vennék figyelembe, de az önkormányzatnak lehetősége lenne a $100 \%$-ot meghaladó kulcs alkalmazására is. A helyi SZJA bármilyen emelése már nem módosítaná a támogatási rendszert, hanem a helyi bevételeket növelné. A pótadót az APEH szedné be és utalná át a településeknek. Az általános központ/helyi adóteher nem változna.

A szimuláció alapján az SZJA "összes" bevételhez viszonyított aránya telepúlésenként változik, de általában magasabb a nagyvárosokban, városi körzetekben és a nagyobb településeken, mint a kisebb településeken (4. táblázat). Az SZJA lényegében városok számára kedvezö bevétel, amelyet inkább az iparilag fejlett körzetekben szednek be. A városi/falusi SZJA között látszólagos aránytalanságot azonban maga a jövedelemadó rendszer okozza (mezögazdasági 
SZJA mentesség). A településhálózat ugyancsak befolyásolja az SZJA bevételt. A kisebb községek az észak-, illetve a dél-dunántúli régiókban találhatók.

A falvak, falusi körzetek és a kisméretü önkormányzatok esetében az SZJA költségvetési aránya alacsonyabb, mint a nagy településeken. A központi SZJA kulcsok csökkentése és ezzel egyidejüleg a helyi önkormányzatok helyi SZJA pótadó kivetésére a helyi jövedelmeket érintetlenül hagyja, feltéve, hogy azonos (100\%-os) pótadót vetnének ki. A 2000 fönél kisebb népességü önkormányzatokban a 100\%-os pótadó a bevételek 14\%-át tennék ki. A települések második csoportjában (2000-10000 lakos) a jelenlegi SZJA bevétel magasabb, kb. az összes bevétel $18-20 \%$-a. A 10.000 lakos feletti városok önkormányzati pótadója a helyi bevételek több, mint 20\%-át adná.

A szimuláció az 1991. évi költségvetési tervszámokhoz képest másfajta forráselosztást eredményezett. A városok és a 10.000 lakos feletti települések szimulált bevételei kisebbek a tervszámoknál, ugyanakkor a kisebb önkormányzatok nyernek, mivel a helyi bevételek nagyobb részét kitevő támogatások határozzák meg azok pénzügyi helyzetét. A legkisebb településeken, ahol az SZJA részaránya alacsony, a helyileg kivetett pótadó csak politikai veszteségek árán lenne növelhető. Itt szükséges az SZJA különbségek valamiféle kiegyenlítésére.

\section{TÁBLÁZAT}

Az SZJA aránya az összes bevételen belül

(Proportion of Personal Income Tax in the Total Revenue)

\begin{tabular}{|l|c|c|}
\hline & $\begin{array}{c}\text { SZJA \%-a az összes } \\
\text { bevételben }\end{array}$ & SZJA megoszlása \\
\hline Közigazgatási jogállós szerint & & \\
\cline { 2 - 3 } $\begin{array}{l}\text { Város (169) } \\
\text { Község (2900) }\end{array}$ & 27,7 & 78,5 \\
\cline { 2 - 3 } Népesség nagyság szerint & 17,5 & 21,5 \\
\cline { 2 - 3 } 2.000 & -4.999 \\
\cline { 2 - 3 } 5.000 & -9.999 \\
$10.000-49.999$ & 13,8 & 7,5 \\
$50.000-99.999$ & 18,2 & 8,2 \\
\cline { 2 - 3 } $100.000-$ & 19,6 & 5,9 \\
\cline { 2 - 3 } Átlag/ÖSszesen & 21,3 & 20,2 \\
\cline { 2 - 3 } & 24,9 & 9,3 \\
\cline { 2 - 3 } & 34,1 & 48,9 \\
\cline { 2 - 3 } & 24,7 & 100,0 \\
\hline
\end{tabular}

* Ósszes bevétel $=\mathrm{SZJA}+$ normativ támogatás + kiegészitő támogatás

Forrás: Bird és Wallich (1992) 99. 0. alapján

IMF szakértöi javaslat ${ }^{3}$

A szakértöi bizottság olyan időszakban tett látogatást Magyarországon, amikor az SZJA megosztásban az önkormányzatoknak juttatott hányad csőkkentése helyett az arány növelését vette célba a kormányzat. A szakértök hangsúlyozták, hogy ez inkább a magasabb bevétellel rendelkezö önkormányzatok számára kedvezöbb, $s$ nem jelenti az önkormányzatok pénzügyi önállóságának általános - a teljes önkormányzati körre kiterjedö - fokozódását. A megosztási aránnyal kapcsolatos viták helyett ez a szakértői csoport is inkább az SZJA pótadóztatása, illetve helyi 
jövedelemadó alkalmazása mellett érvelt. A bizottság elsősorban a skandináv gyakorlat példáira (Svédország, Dánia) hivatkoztak. Javaslatuk szerint a helyi jövedelemadó bevezetését az tenné lehetóvé, ha a központi SZJA egyes adósávjainak marginális kulcsát egységesen 10-12\%-kal csökkentenék.

Mivel a bizottság csupán két hetet tartózkodott Magyarországon, ezért modellszámítások készítésére nem volt lehetősége. Így javaslatukban a helyi jövedelemadó alkalmazásához szükséges technikai szerkezet és az adó alkalmazását elỏkészítō időtábla (menetrend) fölvázolását vállalták fơl. A bizottság az egysávos adókulcs alkalmazását szorgalmazta, mivel az nem nagyítja föl a fejenkénti adóalapokon fennálló eltérések hatásait, a marginális adókulcs egyenló mértékben növekszik mind a magas, mind az alacsony szintű bevételeknél, és ezért védelmet nyújt a rendkívül magas felső marginális értékek keletkezése ellen.

Az IMF delegáció is úgy találta, hogy a helyi jövedelemadó adminisztrációját célszerü az APEH-ra bízni. Nem látták szükségét az adóelöleg levonási rendszer változtatásának sem a pótadóztatás bevezetésével. Lényegesebb kérdésnek tekintették az adókulcs helyi meghatározását. Fölhívták a figyelmet arra, hogy szükséges egy kötelezó érvényủ szabványos pótadókulcs elöírása, amelyet a legkedvezótlenebb jövedelmi adottságú önkormányzatoknál is alkalmazni kell. Ezt azért látják fontosnak, mert nem tartják helyénvalónak egy negatív adóverseny kialakulását az önkormányzatok között az alacsony adókulcsokkal, hogy azzal teremtsenek vonzerŏt a vállalkozók ottani megtelepedéséhez. Szükségesnek tartják a minimális pótadókulcs alkalmazását azért is, mert ezzel biztositott a helyi önkormányzat minimális erőfeszítése a helyi források képzésére, $\mathrm{s}$ ez ađhat alapot a kiegészitơ támogatás alkalmazásához. A szakértő̉k felső pótadókulcs korlát elöírását nem kezdeményezték.

A jelentés tartalmazott még néhány megfontolásra méltó technikai javaslatot is a pótadóztatással kapcsolatban. Ahhoz, hogy az önkormányzat következő évi bevétele, s az ahhoz szükséges adókulcs tervezhetö legyen, a központi kormányzatnak (július végéig) biztosítania kell a várható adóalapra vonatkozó számításokat az adott önkormányzatra vonatkozóan. Ezután az önkormányzatnak döntést kell hoznia az adókulcsra vonatkozóan, amelyröl a számított bevétellel egyetemben tájékoztatnia kelI a központi kormányzatot (szeptember vége) egyfelöl a következő évi SZJA havi utalásának érdekében, másfelól a munkáltatók (az adóelőleget befizetơk) időben történơ tájékoztatása érdekében. Mivel az utalt SZJA részletek és a tényleges adóbevétel között bizonyosan eltérés lesz, ezért szịkséges szabályozni a tényleges adóbefizetések szerinti utólagos elszámolást az önkormányzat és az adóadminisztráció között.

Dovey-Péteri féle javaslat ${ }^{4}$

A szerzők számításaikat az 1993. évi tényadatokon, de az 1995. évre érvényes SZJA megosztás önkormányzati részének (25\%) kiváltására végezték el. A megosztásról a pótadóztatásra történỏ átállás modellezésénél az alábbi feltételezéssel éltek:

1. Az önkormányzatok összesen a pillanatnyi SZJA bevétel 25\%-ához jutnának, ha egy normatív kulcs mellett vetnék ki a pótadót. 
2. A központi adókulcsokat olyan mértékben csökkentenék, hogy az átlagos pótadó-kulcs esetén az adófizetők pozíciója nem változik.

3. Az önkormányzatok egy minimális és egy maximális kulcs közé eső mértékben kapnának jogot a pótadó kivetésére.

Kétféle pótlékolási lehetőséget tárgyaltak a szerzők. Az első esetben a központi SZJA kulcsok egységes növelésével történik a pótlékolás. Ahhoz, hogy az összes SZJA-n belâl továbbra is a $25 \%$ legyen az önkormányzati rész, becsléseik szerint kb. 7\%-os kulcsot kell alkalmazni. Tehát ennyivel kell csökkenteni a központi SZJA adósávonkénti kulcsait (5. táblázat). A második esetben az egyes adósávok kulcsaihoz viszonyított pótlékolás mértéke egységes. A $25 \%$-os önkormányzati rész fenntartásához, így minden egyes adósáv kulcsát 20\%-kal kell mérsékelni. Ez a módszer a helyi adó szintjén - a központi SZJA-val megegyező eloszlásban - is fenntartja az SZJA progresszivitását.

\section{TÁBLÁZAT}

A központi SZJA kulcsok alakulása pótadóztatás mellett (\%)

(Central Tax Rates at Surcharge on Personal Income Tax \%)

\begin{tabular}{|c|c|c|c|c|}
\hline \multirow{2}{*}{ Adósávok } & \multicolumn{2}{|c|}{$\begin{array}{c}\text { Központi adókulcs egységes } \\
\text { növelése }\end{array}$} & \multicolumn{2}{c|}{$\begin{array}{c}\text { Egységes pótadó az SZJA } \\
\text { százalékában }\end{array}$} \\
\cline { 2 - 5 } & $\begin{array}{c}\text { Központi } \\
\text { kulcsok }\end{array}$ & $\begin{array}{c}\text { Helyi pótadó } \\
\text { kulcs }\end{array}$ & $\begin{array}{c}\text { Központi } \\
\text { kulcsok }\end{array}$ & $\begin{array}{c}\text { Helyi pótadó } \\
\text { kulcs }\end{array}$ \\
\hline $0-110.000$ & 0 & 0 & 0 & 0 \\
\hline $110.001-150.000$ & 13 & +7 & 16,0 & $+4,0$ \\
\hline $150.001-220.001$ & 18 & +7 & 20,0 & $+5,0$ \\
\hline $220.001-380.000$ & 28 & +7 & 28,0 & $+7,0$ \\
\hline $380.000-550.000$ & 33 & +7 & 32,0 & $+8,0$ \\
\hline $550.000-$ & 37 & +7 & 35,2 & $+8,8$ \\
\hline
\end{tabular}

* 1993. évi adótábla alapján

Forrás: Davey-Péteri (1995) 18-19. o. alapján

Véleményük szerint a pótadó bevezetése egyszerübb, ha hatása mind az adófizetőkre, mind az önkormányzatokra semleges egy adott sztenderd kulcs mellett (második változat). Ez azt jelentené, hogy az önkormányzatok egységes százalékos pótadót vetnek ki a teljes befizetett adóra. Ha a sztenderd kulcs $25 \%$ lenne, akkor a korábbi központi-helyi arány fenntartásához $20 \%$-kal kell csökkenteni az országos adó minden sávját. Ugyanakkor az önkormányzatok szabadon határozhatnának meg a sztenderd kulcsnál magasabb vagy alacsonyabb kulcsokat. Így a sztenderd kulccsal keletkezó adóbevételhez képest bevételi többletulk vagy kiesésük származna. Ez adott település adófizetójét tekintve a korábbiaknál magasabb, illletve alacsonyabb adóterhet jelentene. Amennyiben a $25 \%$-tól eltéró sztenderd kulcsot alkalmaznának, akkor a központi és helyi kormányzatok között a források újraelosztását eredményezné. Ez szükségessé teheti a támogatási rendszer átalakítását is. 
A sztenderd kulcstól való eltérés elképzelhetỏ az önkormányzatok teljes döntési szabadságával, vagy korlátok beépítésével. A szerzők egy 20-35\%-os tartományba eső pótadóztatást tartanának megfelelönek. Így a pótadó kulcsok szélső értékeit tekintve a jelenlegi SZJA részesedés $80-140 \%$-a közé eső összeget jelentenének. Számításaikat a szélső értékeken történő becsléssel végezték el, amelyben feltételezték, hogy

- valamennyi, az átlagosnál magasabb egy före jutó SZJA részesedéssel rendelkezö onkormányzat a maximális 35\%-os pótadó kulcsot vezeti be, illetve

- valamennyi, az átlagosnál alacsonyabb egy före jutó SZJA részesedéssel rendelkezठ ơnkormányzat a minimális $20 \%$-os pótadó kulcsot vezeti be.

- Budapestet kihagyták a modellböl a két önkormányzati szint közötti megosztás bizonytalanságai miatt.

A fenti feltételek mellett a gyengébb jövedelemtermelö képességủ önkormányzatok SZJA bevétele a jelenlegihez képest $20 \%$-kal csökkenne, mig kedvezőbb jövedelmi helyzetü önkormányzatoké 40\%-kal növekedne. Összességében a helyi önkormányzatok teljes SZJA bevételei 19\%-kal növekednének a megosztott SZJA esetén kapott forrásokhoz képest, továbbá a helyi részarány a 25\%-ról 37\%-ra nőne. (A szerzők azonban hangsúlyozzák, hogy a pótadó bevezetése melletti fö érv nem a többletbevételek elöteremtésének lehetösége, hanem a helyi adóztatás és költekezés döntéseire vonatkozó elszámolhatóság átadásában rejlik.)

A szerzők foglalkoztak az adóadminisztráció kérdéseivel is. Az SZJA-val foglalkozó tisztségviselökkel folytatott konzultációik szerint a pótadóztatás bevezetése nem igényelné a jelenlegi adóigazgatási eljárás jelentős módosítását. Az adminisztratív terhek elsósorban a munkáltatóknál jelentkeznek, mivel az egyes dolgozóik fizetéséből a lakóhelyek különbőzősége miatt eltérő kulcsokkal kell az SZJA elöleget levonni. Ez a számitógépes bérszámfejtést alkalmazó munkáltatók számára nem jelenthet problémát.

Összegezve a személyi jövedelmek pótadóztatásának szakértői javaslatait a kővetkezö megállapításokat tehetjük:

- Mindegyik javaslat kiindulópontja az, hogy az éppen aktuális központi-helyi kormányzat közötti SZJA megosztásban a helyi ơnkormányzatokra jutó részt egy helyi döntésü SZJA pótadóval váltanák ki úgy, hogy a kơzponti marginális kulcsokat a bevételek kivánt megoszlását eredményezỏ szintig csökkentenék. Hangsúlyozzák, hogy ezáltal az összes SZJA teher változatlan marad.

- Ugyanakkor az önkormányzatok lehetöséget kapnának arra, hogy egy a központ által megállapított sztenderd (normativ, átlagos) helyi SZJA pótadó kulcstól lefelé vagy fölfelé eltérjenek.

A) A sztenderd kulcstól lefelé való eltérés az egyes adófizetők összadóterhének csökkenését eredményezi, amely tovább erősítheti a jelenlegi kiadási igényszint és a bevételi kapacitások (saját források + állami transzferek) közötti feszültséget. Változatlan kiadási szükséglet mellett a csökkenő SZJA bevételt pótolni kell. Ez fölerősiti a többi forráselem növelésének igényét (kiegészitő SZJA támogatás, vagy normatív támogatás erőteljesebb emelése, vagy egyéb helyi adók bevételi kapacitásának növelése, vagyon felélés, stb.). A probléma oldását jelentheti egy minimális marginális adókulcs elöirása, amely az egyes önkormányzatoktól elvárható minimális adóerőfeszitést jelentené. Tehát az SZJA pótadóztatása nem 
a választható helyi adók körét bövítené, hanem kötelezö érvényủ lenne. Az átlagos marginális SZJA adókulcs csökkenésnek lehet pozitív hatása is, pl. emelkedhet az adófizetési hajlandóság, illetve a beszedési hatékonyság. ${ }^{5}$

B) A sztenderd kulcstól felfelé történö eltérés többletbevételt eredményezhet az egyes önkormányzatok számára. Mivel azonban a pótadóztatás kiindulópontja minden esetben az aktuális marginális kulcsrendszer volt, ezért a sztenderd kulcs feletti adóemelés az aktuálisnál magasabb marginális kulcsokat eredményez. Ennek politikai ára esetleg nagyobb lehet, mint a javuló szolgáltatásokból származó látható előnyök. Az is előfordulhat, hogy az emelkedỏ kulcsok hatására csőkken az adófizetési hajlandóság és a beszedési hatékonyság. A probléma oldását jelentheti a pótadó kulcs maximális értékének meghatározása. (A világbanki szakértők és a Davey-Péteri javaslat felülről is korlátozza az SZJA pótadó rendszerét, az IMF jelentés viszont nem szab felső korlátot a helyi pótadóztatásnak.)

C) Az SZJA megosztási javaslatokat mindegyik szakértôi csapat az önkormányzati finanszírozás általános keretei közé ágyazva tárgyalja. Hangsúlyozzák a saját forrás lehetôségek körének bővülését. Az SZJA pótadóztatásán túl a helyi érték alapú ingatlan adóztatás fejlesztését emelik ki. Ez az adó ún. tárgyi adó, de az adófizetést ez esetben is befolyásolja az adófizetők teherbíró képessége, hiszen az adót döntően nem az adóköteles ingatlan hasznosításából származó jövedelmükből fizetik. Ha az SZJA pótadóztatása és a helyi ingatlan adóztatás fejlesztése ugyanazon időszakban történik, akkor a központi SZJA kulcsok csökkentésének modellezésében mindkét adót figyelembe kell venni. Hiszen az SZJA-t fizetők számára az ingatlanadó plusz adóteherként jelentkezik. Ebbő̉ következỏen a két adónem egyuittes fejlesztése esetén csak a korábbiaknál kisebb összes SZJA bevételböl szabad kiindulni.

- Mindhárom javaslat a pótadó adminisztrálását a központi adóigazgatáshoz rendeli, jelezve, hogy az átállás inkább az SZJA elölegeket utaló munkáltatóknál okozhat kezdetben zavarokat. Problémát jelenthet ugyanakkor a helyi költségvetésekben kétéves csúszással megjelenő adóbevétel (a pótadó elvileg az adott pénzủgyi-tervezési idószak költségvetési egyensúlyát hivatott szolgálni), valamint a következó évre érvényes pótadó kulcsok eldöntésének idöpontja.

A) A kétéves csúszás problémája

A jelenlegi rendszerben kicsit fólnagyított ez a probléma, mivel egy beálit rendszerről van szó. A tervezés szempontjából megfelelö, mert stabil, az év közben nem változó forrásról van szó. A finanszírozással sem lehet elvben gond, hiszen fedezete a folyó befizetés, amelynek havi befizetései nyilván meghaladják a két évvel ezelőtti befizetések alapján az önkormányzatokat megillető folyó átutalásokat. A problémát a megosztási aráıyok évenkénti változtatásai okozzák, amelyröl csak novemberben dőnt a parlament. Ez a konfliktus viszont oldható egy-egy több évre meghirdetett programmal (pl. az 1996-1998-as periódusra alkalmazott metódus), vagy legalább választási ciklusonkénti időszakokra nem célszerủ változtatni a megosztást.

B) A pótadó kulcsok meghatározásának ideje

Az IMF szakértők javaslata szerint ennek szeptember 30-ig meg kell történnie, hogy minden érintett időben fơl tudjon készülni a változásra. A megvalósítást erőteljesen befolyásolja, hogy a játékszabályokat meghatározó keretek minden bizonnyal a következő néhány évben is jelentősen módosulhatnak. Ezekröl a keretekröl a Parlament azonban csak november-december folyamán dönt. A javaslat szerinti dátumnak csak akkor lenne realitása, ha az általános szabályozási keretek (központi adóváltozások, állami kőltségvetés) már augusztus végén rendelkezésre állnának. 
Problémapontok az SZJA pótadóztatásával kapcsolatban:

- Magyarországon jelentős kedvezmények csökkentik az adóalapot, vagy magát az adót;

- magas az adóeltitkolás aránya;

- a mezőgazdasági foglalkoztatottak jövedelmei csak kismértékben adóznak.

Mindhárom tényezö torzitja az adóbevételek területi eloszlását. Az elsỏ két tényező koncentráltabban jelenik meg a gazdaságilag erősebb térségekben (föváros, nagyvárosok), a mezőgazdasági népesség pedig koncentráltabban jelenik meg egyrészt a községekben, másrészt - területileg tekintve - az Alföld településeiben. $A$ fenti torzitások ujjratermelödnek az SZJA pótadóztatásával. Az adóterheket is ugyanaz a réteg - döntöen az alkalmazotti bérböl élök - viselnék.

\section{A hazai helyi adórendszer}

A megreformált helyi adórendszer napjainkra kezd beérni. Ez, a kezdetben viszonylag alacsony kulcsok ellenére vitathatatlan. Számos önkormányzatnál kimutatható, hogy kezdi tudatosan formálni adópolitikáját és - gyakori esetben a helyi adófizetők nyomására (nyilvánosság, elszámolhatóság) - azt kezdik összehangolni egy helyi településfejlesztési-, gazdaságfejlesztési politikával. A helyi adók bevételi kapacitása is egyre számottevóbb, azonban az adóbevételek gyors fejlődését - az adót bevezetỏ önkormányzatok és a bevezetett adótípusok számának fokozatos bövülésén túl -, döntỏ mértékben (1997-ban 83,9\%) az iparüzési adó bevételek képezik (1. ábra). Ez az adótípus azonban csak a jelentősebb gazdasági kapacitásokkal rendelkező önkormányzatok számára hoz - egyre komolyabb bevételeket.

A sikeresnek mondható helyi adórendszerrel kapcsolatban azonban számos probléma is fölvethető. Ezek a következök:

- A kivethetỏ helyi adótípusok fele a lakosságot, a másik fele a vállalkozásokat adóztatja. Sajnos a jelenlegi rendszer - részben a súlyos központi adóterheknek köszőnhetően - a lakosság helyett a vállalkozások adóztatására ösztönzi az önkormányzatokat. Az iparüzési adó, a vállalkozások kommunális adója, a vállalkozások építménye és telke után fizetett vagyoni típusú adók adják a helyi adóbevételek több, mint $90 \%$-át.

- Pontosan azonban nem állapítható meg az, hogy mennyi a lakossági és mennyi a vállalkozói befizetés, mivel az adóösszesítéshez kötelezően alkalmazott központi szoftver figyelme erre nem terjed ki. Szükséges lenne a szoftvert úgy átalakítani, hogy lehetőség legyen az építményadó, a telekadó és a kommunális adó esetében a vállalkozások és a lakosság befizetéseinek külön kezelésére. Ettől még a központi jelentés készülhetne az öt adótípus bontásában, de legalább helyi szinten, a helyi adópolitika formálásához oly fontos információ nem veszne el.

- Az iparüzési adó bevételek koncentráltan a föváros, a nagyvárosok és a fejlettebb gazdasági bázissal rendelkező telepulések forrásképző elemei. A nagyfokú koncentráció miatt fölvetődött az iparüzési adó egy részének elvonása kiegyenlítési célokra (francia példa). Egy másik vảltozat ennek az adónak a társasági adó pótadójává alakitását javasolja (Illés 1996). A jelenlegi keretek között egyik javaslat sem elfogadható. Ugyanis az adó kivetése - a helyi adók mai szabályozása szerint - csupán lehetőség, amellyel élhet az 
ơnkormányzat. Ezzel lényegében büntetnék azt az önkormányzatot, amely saját erôfeszítéseket tesz forrásai bỏvítésére. A pótadóvá alakítása is azért problémás, mert jelenleg az iparüzési adó kivetése nem kőtelezỏ. Ráadásul az adókulcsokat is szabadon határozhatják meg az ơnkormányzatok a tőrvényben megszabott felső határ mértékéig.

- Az egyelöre szlúk sávban mozgó lakossági adóztatáson belül továbbra is rendkívull mérsékelt a lakásingatlanok adóztatása. Érdemes újra átgondolni az ebben az adótípusban rejlö lehetőségeket. Mivel valamennyi településen van lakóingatlan, ezért az SZJA mellett a legszélesebb kőrt befogó adótípus. Söt, mivel az ingatlan látható, a tulajdonos fôlderithetô, ezért olyan lakossági köröket is képes bevonni az adózásba, amelyek az SZJA kötelezettségek alól ki tudtak bújni. Érvként szolgálhat az is, hogy az ingatlan értéke magában foglalja az onkormányzat által nyújtott szolgáltatások színvonalát is. Figyelemre méltó, hogy Magyarországon a lakosság ingatlanvagyona a gazdaság fejlettségéhez és (az ismert, bevallott) jövedelmi színvonalához képest kiemelkedően nagy.

\section{1. ÁBRA}

Helyi adó bevételek megoszlása, 1991-1996

(Distribution of Local Tax Revenues, 1991-1996)

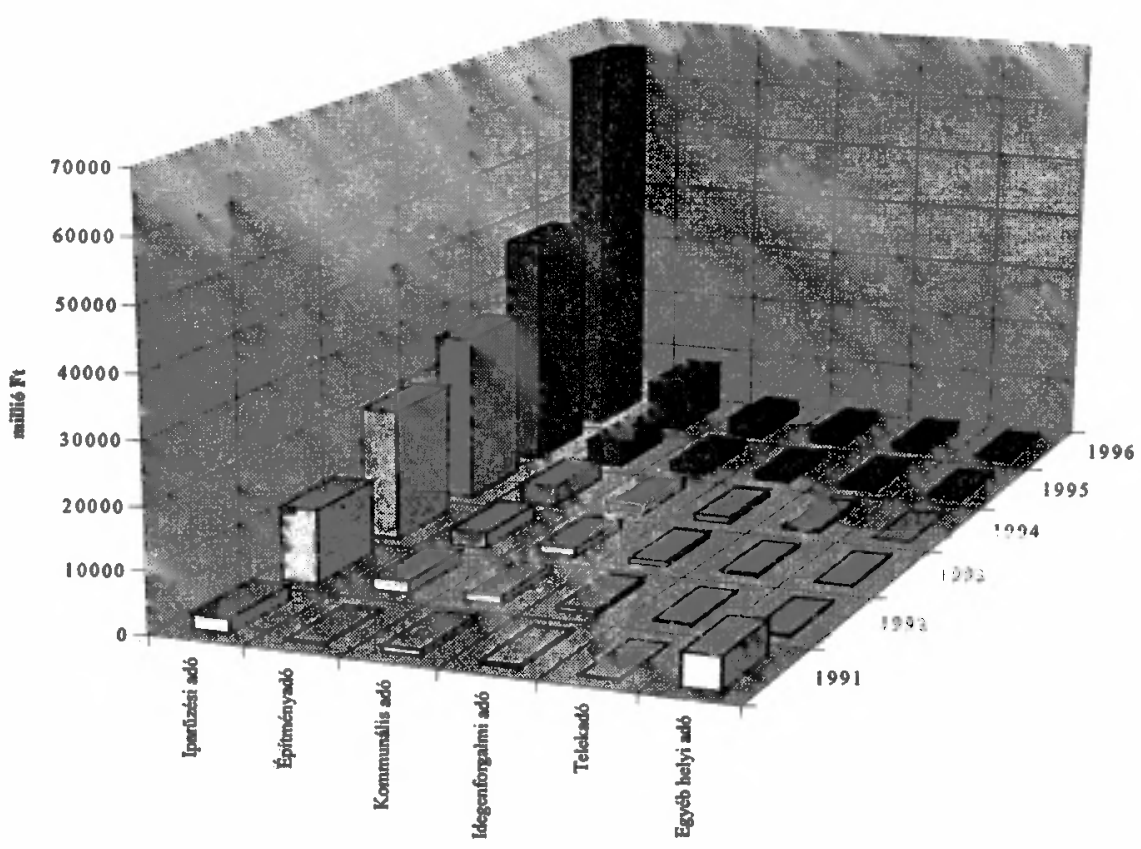

Forrás: Pitti (1994), Fehérvári (1995), APEH SZTADI, BM TÁKISZ 
- Az ingatlanadózás fejlesztésével kapcsolatos teendőket több alkalommal kifejtettük (Illés 1994 és 1996, Lados 1993 és 1995), azok egy kivétellel ma is érvényesek (a kivételt a központi mentességi kör jelentős csökkentése képezi, amelyet a helyi adó törvény 1995. évi módosításai tettek meg):

- az ingatlan-nyilvántartások korszerüsítése, naprakésszé tétele, elektronizáció befejezése (szükséges lenne annak fölmérése, hogy a német kormányzati támogatással évekkel ezelött megindult fóldhivatali program teljesítése hol tart, hiszen a befejezést eredetileg 1998-ra tervezték, s ez az ingatlanadó fejlesztése szempontjából rendkívül fontos);

- szükséges a megbízható és általánosan elfogadott értékelési eljárások kidolgozása (az Egyesült Királyságban a tömeges értékbecslés módszerével egy év alatt vissza tudtak állni a fejadóról a forgalmi értéken alapuló ingatlanadóztatásra);

- szükséges mind az önkormányzatok, mind a lakosság fölkészítése az ingatlanadóztatásra, ez a legkeményebb időtényezö jelenleg a rendszer bevezetésével kapcsolatban - a jó elökészítés mintegy három-öt évet vesz igénybe, tehát az értékalapú ingatlanadóztatás általános bevezetésének mai állapotok szerint csupán 2002 körül van esélye.

- Kevéssé használják ki az önkormányzatok a telekadó kínálta lehetőségeket. A többség abból indul ki, hogy kevés az ilyen típusú területe, $s$ amelyröl csak politikailag nehezen védhető magas adókulcsok alkalmazásával lehetne komolyabb bevételt beszedni. Tehát a gyenge jövedelmi potenciálja miatt kevéssé használják ezt az adótípust. Felkészitő programokon jobban szuikséges hangsúlyozni azt, hogy az adó nem feltétlenül bevételi érdekeket szolgál, lehetséges az adót telepưléspolitikai eszkőzként is alkalmazni, s ennek egyik kiváló példája a telekadó, amelynek segitésével egyrészt felgyorsitható egyegy elhanyagolt terület fejlesztése, másrészt segithet a nagyobb települési beruházások környezetében kialakuló spekulációs célú telekvásárlások gátolásában. (Az adó lefelé téríti el a telek, az ingatlan piaci árát).

\section{A kiegyenlítő támogatások rendszere}

A helyi források - pl. helyi adók, pótadó rendszerek - szerepének növelésekor szuikséges annak vizsgálata, hogy az önkormányzati saját források eloszlása milyen mértékben járul hozzá a régiók és településtípusok közötti egyenlötlenségek mérsékléséhez vagy felerösödéséhez. Éppen ezért alapvető kérdés a kiegyenlitö támogatások konstrukciója, ennek áttekinthetösége és a helyi források kihasználására való ösztönzés fönntartása.

A forrás-orientált pénzügyi tervezésben a megosztott SZJA és a normatív támogatás komplementer elemek. A központban maradó SZJA a normatív módon elosztott források alapjává válik. Vajon tényleg tapasztalható kiegyenlitődés az eddigi megosztási arány csökkentések esetén? Úgy tưnik, hogy az elmúlt években döntöen a leggazdagabb önkormányzat, a föváros forrásszerkezetének alakulása követi ezt az elvet. Az SZJA részesedés csökkenésével párhuzamosan a normatív támogatásokon belüli súlya is mérséklödött Budapestnek (6. táblázat). 


\section{TÁBLÁZAT}

Az SZJA bevételek és a normativ támogatás önkormányzat típusonkénti megoszlása (\%)

(Personal Incoma Taxes and Normative Grants by Levels of Territorial Administration)

\begin{tabular}{|l|r|r|r|r|r|r|r|r|}
\hline & \multicolumn{4}{|c|}{ SZJA + SZJA kiegészítés } & \multicolumn{3}{c|}{ Normatív állami hozzájárulás } \\
\hline & 1993 & 1994 & 1995 & 1996 & 1993 & 1994 & 1995 & 1996 \\
\hline Budapest & 30,8 & 31,6 & 28,3 & 27,5 & 16,9 & 16,8 & 16,4 & 15,8 \\
\hline Megyék & 0,0 & 0,0 & 0,7 & 2,5 & 9,0 & 9,1 & 9,3 & 10,1 \\
\hline Nagyvárosok** & 21,3 & 21,9 & 21,0 & 20,4 & 21,0 & 20,7 & 21,3 & 20,8 \\
\hline Többi város & 22,4 & 21,9 & 22,7 & 22,3 & 23,9 & 24,0 & 24,5 & 24,6 \\
\hline Községek & 25,5 & 24,6 & 27,3 & 27,4 & 29,2 & 29,5 & 28,5 & 28,7 \\
\hline Összesen & 100,0 & 100,0 & 100,0 & 100,0 & 100,0 & 100,0 & 100,0 & 100,0 \\
\hline
\end{tabular}

* Az adott év kơzigazgatási beosztása szerint.

** Valamennyi megyeszékhely és egyéb megyei jogú város

Forrás: TÁKISZ adatbázis alapján saját számítás

Érdekes módon azonban ez csak - az SZJA kiegészító támogatás miatt - az SZJA esetében jelentkezik a községeknél. A normatív támogatásoknál a források inkább a megyei, illetve a városi önkormányzatok felé csoportosultak át. Ez annak a normatíva rendszernek köszönhető, amelyben számos elem a városi, illetve középszintủ szolgáltatásokat veszi figyelembe, $\mathrm{s}$ azok kulcsát rendszerint az adott szolgáltatás átlagos szintjéhez közelebbi tartományban határozza meg. Ugyanakkor a kőzségi környezetben is müködtetett feladatok esetében a normatíva az átlagkőltségtől távolabb helyezkedik el.

Valójában több olyan támogatás is van az önkormányzati finanszírozás rendszerében, amely teljesen, vagy jelentős részben kiegyenlítő célokat szolgál. Bizonyos értelemben a feladatorientált támogatások is idesorolhatók, hiszen minden tanuló, minden szociális támogatásra vagy egészségulgyi ellátásra szoruló ember után ugyanolyan támogatást juttat. E hatásuk mellett azonban e támogatások elsősorban az állam által felvállalt és ellátott egy-egy feladathoz kőtődnek, funkciójuk nem elsősorban a kiegyenlítés, hanem konkrét feladatellátás.

A támogatások egy másik részénél valóban a kiegyenlító funkció dominál. Ezek a támogatások azonban elaprózottan és tơbb helyen lelhetők fỏl. Néhány tényezöt a "helyben maradó" SZJA ún. feladattal terhelt csoportjában találhatunk 1997-ben. Ezek a következök:

- SZJA kiegészítỏ támogatás (19,0 Mrd Ft - községek: $7.073 \mathrm{Ft} /$ fö-ig, városok: $8.643 \mathrm{Ft} / \mathrm{fo}$-ig)

- községek általános támogatása (5,8 Mrd Ft - 2 millió Ft/község)

- a telepulési önkormányzatok telepulési igazgatási, kommunális és sportfeladatainak támogatása (19,3 Mrd Ft - $1.842 \mathrm{Ft} / \mathrm{f}$ )

- társadalmi-gazdasági és infrastrukturális szempontból elmaradott, valamint a súlyos foglalkoztatási gondokkal küzdő - kormányrendeletben meghatározott - önkormányzatok támogatása (2,7 Mrd Ft - $1.600 \mathrm{Ft} / f 0 ̈)$. 
$\mathrm{Az}$ utóbbi három cél korábban a normatív támogatási rendszer eleme volt. A felsorolt kiegyenlítési célokra, tehát az SZJA-ból elszámolható keretek között, 46,8 Mrd Ft-ot fordítanának. A helyben maradó SZJA-t terheli a megyei önkormányzatoknak juttatott egyes támogatások, amely itt egy kicsit kakukktojásként megjelenő elem. Szerencsésebb volna (bár politikailag nem hangzik olyan szépen), hogy a megosztási arány $22 \%$. A központban maradó $78 \%$ pedig a normatív támogatások meghatározott elemeit finanszírozzák. Ugyanis a jelenlegi konstrukcióban a kormányzat 1997-ben 16\%-nyi, 1998-ban 20\%-nyi SZJA-val tud elszámolni, de a maradék 62, illetve 60\% központban maradó SZJA elköltési csatornái nem ismertek, a nyilvánossága hiányzik. (Természetesen, mint ahogy azt a megosztott SZJA-val foglalkozó fejezetben jeleztük is, a központban maradó SZJA-val úgy számolunk, hogy az teljes egészében a normatív támogatások alapját képezi ${ }^{6}$. Ebből a szempontból a normatív támogatások fedezete sem transzparens, hiszen nem láttunk még olyan felosztást, hogy pl. az adott évben normatív támogatás címen fölosztott források 80\%-át a központosított SZJA, 20\%kát pedig az ÁFA befizetések fedezik.)

A normatív állami hozzájárulások között két célt sorolhatunk a szorosabban vett kiegyenlítési elemek közé:

- a települési önkormányzatok települési igazgatási, kommunális és sportfeladatainak támogatása ( $3 \mathrm{Mrd} \mathrm{Ft} \mathrm{-} 312 \mathrm{Ft} / \mathrm{fö}$ )

- közművelödési feladatok támogatása (1,5 Mrd Ft - $157 \mathrm{Ft} /$ fö)

Önálló költségvetési tételként szerepelnek még az állami költségvetésben különbözö fejlesztési, illetve müködést segitő támogatások, amelyek további 69,0 Mrd Ft-ot képviselnek:

- cél- és címzett támogatások (39 Mrd Ft)

- területi kiegyenlítést szolgáló fejlesztési célú támogatások ( $8 \mathrm{Mrd} \mathrm{Ft)}$

- müködésképtelenné vált helyi önkormányzatok kiegészitő támogatása (6 Mrd Ft)

- önhibájukon kívül hátrányos helyzetben lévő (forráshiányos) helyi önkormányzatok támogatása (6 Mrd Ft).

Ez a széttagolt, mintegy tíz támogatási elemböl álló rendszer 1997-ben mintegy 110 Mrd Ft-ot juttat az önkormányzatok számára, amely a várható önkormányzati összforrás több, mint 10\%-a. A fenti kört tovább bővithetik a Területfejlesztési Alapból (TEFA) elnyert források, ugyanakkor a céltámogatásokat valójában nem szabadna ebbe a körbe sorolni, mivel a jellemzöen legalább $60 \%$-os saját forrás igényt a gyengébb jövedelmi poziciójú önkormányzatok nem tudják teljesiteni, igy hátrányos helyzetben vannak a pályázati versenyben. (Az meg további problémákat okozhat, ha a beruházási fedezetet mégis sikerül összehozni, de a későbbi müködtetésnek nincsen fedezete.)

Az 1991-1994 közötti időszakban a fejlettebb megyék (pl. Györ-Moson-Sopron) lényegében nem jutottak forráshoz a 18,5 Mrd Ft-nyi TEFA-ból. Ugyanakkor a jelentős saját forrásokat is megmozgató, az adott idôszakban 52,3 Mrd Ft-ot felhasználó céltámogatási rendszerben magas részarányt képviselnek. (A vizsgált időszakban a Györ-Moson-Sopron, Vas és Zala megyék alkotta Nyugat-dunántúli régióban a TEFA csupán 2,7\%-a, míg a céltámogatások 17,7\%-a csapódott le.) 
Célszerú ezt a széttagolt rendszert egy áttekinthetőbb keretbe foglalni vagy egy egységes kiegyenlítỏ támogatási alapba gyüjteni. A támogatás nagyságrendje akkora, amelyre mind a megosztott, mind a pótadóztató helyi SZJA rendszerében a kőzpontban maradó, illetve a központi SZJA nyújthat fedezetet.

\section{A./ Elkülönült fejlesztési és müködési kiegyenlítö tómogatási rendszer}

A fentiekben folsorolt kiegyenlító támogatási célokból két fó csoportot lehetne képezni. Az egyik az önkormányzat folyamatos mükődéséhez biztosítana kiegyenlítő jellegü forrásokat, míg a másik a fejlesztési lehetőségekhez való jutás esélyeit egyenlítené ki.

1. A különbőző jogcímeken kiegyenlítő támogatást kapó önkormányzatok általában fedésben vannak. Ezért az első esetben célszerü az SZJA kiegészitő támogatásba összevonni az eddigi támogatás elemeket: SZJA kiegészító támogatás, községek általános támogatása ${ }^{7}$, telepúlési igazgatási, kommunális, kulturális és sportfeladatainak támogatása, önhibájukon kívül hátrányos helyzetben lévő (forráshiányos) helyi önkormányzatok támogatása, valamint a müködésképtelenné vált helyi önkormányzatok kiegészítő támogatása. Ezt a mintegy 60 Mrd Ft-ot kellene egy támogatási formán - az SZJA kiegészítő támogatáson keresztul - szétosztani.

A jelenlegi SZJA kiegészítési mechanizmusban az önkormányzatok több mint 90\%-a érintett, tehát ez egy megfelelóen széles kört foglal magában ahhoz, hogy a korábbi széttagolt kiegyenlítési célrendszerbe tartozó telepulléseket teljes körủen lefedje. Ezután már csupán azt az egy före jutó SZJA átlagot kellene meghatározni, amellyel az SZJA kiegyenlítésen keresztul szétosztott támogatás a jelenleginek a háromszorosára emelkedne.

2. A fejlesztési támogatások továbbra is mükődtethetők lennének a céltámogatások címszó alatt. Nem feltétlenül szuikséges a címzett támogatások kategória, ha a támogatandó célokhoz úgyis egyedileg rendelik a támogatási arányokat. Egy mátrixban lehetne megadni azt, hogy a támogatott célok az egyes önkormányzati típusoknál milyen mértékủ támogatottságot érhetnek. Így biztosítható a horizontális és a vertikális méltányosság is a támogatásban, mivel valamennyi önkormányzat részesedhet fejlesztési célú támogatásban, de támogatás mértéke a sajátos helyzetek figyelembe vételével eltérő lehet.

Deklarálni lehetne azt, hogy mindkét támogatásnak a központban maradó SZJA az alapja.

Összességében az SZJA bevételeket, ha fenntartjuk a megosztott bevételi sémát, akkor világos elosztási elvek alapján négy féle célra kellene fordítani:

- Helyben maradó SZJA: A rendkívül széles kört érintő kiegyenlités miatt az 1998-ra tervezett 20\%-os direkt SZJA hányad kicsit alacsony értékünek tủnik. 1999-töl ezt célszerú lenne a nettó SZJA bevétel ${ }^{8} 30$ vagy $40 \%$-ára emelni

- Kiegyenlító támogatások: Lényegében az egy-egy támogatási címkébe vont müködési, illetve fejlesztési kiegyenlítő támogatások, az SZJA kiegyenlítő támogatás és a céltámogatás egyulttes osszege, amely a nettó SZJA bevétel 35 vagy 30\%-a. (Magasabb lenne a részarány az alacsonyabb, közvetlenül helyben maradó rész esetén és fordítva.) 
- Normatív yagy feladat-orientált támogatások: A nettó SZJA bevétel 35 vagy 30\%-a. (Magasabb lenne a részarány az alacsonyabb közvetlenull helyben maradó rész esetén és fordítva.) Amennyiben ez nem fedezné a szliksséges támogatást teljes körüen, a hiányzó részt az ÁFA-bevételekböl lehetne feltölteni.

- A központi adóhatóság költségeinek fedezete: Az APEH központi költségvetési szervezet, tehát mükődése az adóbevételekböl biztositott. Éppen ezért jogos elvárás lehet, hogy az önkormányzati forrásként megjelenö, de központilag adminisztrált SZJA bevételek egy része hozzájárulék az APEH fenntartási költségeihez. Ennek maximális mértéke a bruttó és nettó SZJA közötti kulönbözet lehet.

Elkülönuult kőzzponti és helyi SZJA esetén csupán annyit módosulna a képlet, hogy a kőzponti SZJA-ra kell világos megosztási arányokat deklarálni az egyes támogatási típusok kőzőtt.

\section{B./ Egységes kiegyenlitési alap}

A kiegyenlítést szolgáló támogatási alap felosztása viszonylag kis számú, de az önkormányzatok helyzetét jól jellemző mutató alapján történhetne. Öt mutató jöhetne számitásba (Illés 1996):

1. Az önkormányzat múkődési költségei és a helyi forrásokból reálisan megszerezhetö fedezet különbsége.

2. A telepúlés, illetve az önkormányzat népessége.

3. Az önkormányzat ingatlanvagyona, amely fenntartást, felújitást, üzemelést igényel.

4. Az önkormányzat nem-ingatlan vagyona, ami viszont potenciális anyagipénzügyi forrást jelent.

5. A belterületi utak hossza, amely többé-kevésbé arányos az út-, közmü-, közvilágítási-, közterület fenntartási, valamint helyi közlekedési feladatokkal.

A támogatások másik ága a feladatorientált támogatás lehetne, amely funkciójában és gazdaságpolitikai jellegében is kuilönbőzne a kiegyenlitö támogatástól:

- A feladatorientált támogatások esetében a központi kormányzat egy konkrét feladat ellátásában vállal felelösséget és egyben meghatározott teherviselést. $\mathrm{Ez}$ esetben indokolt lehet a teherviselés irányadó megosztásának meghatározása is. Pl. az állami felelósségvállalású ágazatokban (kőzoktatás, egészségúgy, szociális ellátás) összesen $2 / 3: 1 / 3$ az állami támogatás/önkormányzati saját forrás közötti tehermegosztás.

- A kiegyenlítỏ támogatás "monetarizált" támogatás, amelyben a központi költségvetés egyetlen konkrét feladatban, ágazati fejlesztésben sem vállal felelösséget, vagy teherviselést, csak annyit, hogy hozzájárul a müködőképesség fơnntartásához és a különbségek csökkentéséhez. A mutatók és normatívák is csupán kulcsok, amelyek alapján valamely adott - a nemzetgazdaság és a kőltségvetés teherviselö képességének függvényében meghatározott - támogatási alap az egyes ơnkormányzatok kơzött fölosztható. 


\section{Összegzés, javaslatok}

Kiindulópont:

A területi és helyi szinten megjelenö területfejlesztéshez történö kormányzati (költségvetési) szerepvállalás célja:

- a terilleti különbségek mérséklése

- nemzeti szinten is kivánatos folyamatok ösztönzése

Kiegyenlítés csak akkor történik ténylegesen, ha a hátrányos helyzetú térségben lévö önkormányzat is rendelkezik fejlesztési forrásokkal. Ennek alapfeltétele azonban a folyó müködési szükségletek stabil biztosítása.

A jövöbeni kívánatos helyzetet olyan forrásrendszer alkalmazása biztosíthatja az önkormányzatok szintjén, amelyek egyrészt segítik a hazai önkormányzatok pénzügyi önállóságának növelését, másrészt biztosítja a kiegyenlitést is az eltérö jövedelem kapacitású önkormányzatok között. Az elsỏ célt a szabad döntésủ források bövülése szolgálhatja, a második esetben egy szétaprózott rendszert szükséges átláthatóbbá, nyilvánosabbá (transzparenssé) és hatékonyabbá tenni.

A szakértői álláspontok szintjén kezd letisztulni és konszenzus kialakulni abban, hogy a pénzügyi önállóság növelésének két útja javasolt a hazai viszonyok között. Az egyik irány a megosztott SZJA bevételi rendszer átalakítása, központi és helyi döntésü SZJA-vá, a másik a helyi ingatlanadó fejlesztése, az értékalapú ingatlanadóztatás alkalınazása. Az utóbbi időszakban felerősődött az iparüzési adó szerepének hosszú távú felértékelödése is.

A hazai hagyományok szerint bizonyos központi egyenesadóknak a belügyminisztérium által jóváhagyott százalékéban vetettek ki községi pótadókat. Ezek között mind vagyoni, mind (személyi és vállalati) jövedelmi típusú adók szerepeltek. A ma elfogadott nemzetközi gyakorlatban inkább a személyi jövedelmek pótadóztatását alkalmazzák. Ez minden önkormányzat számára bevételi forrást jelenthet, ugyanakkor lehetővé tenné az adóztatás jogának kiterjeszthetését a középszintü önkormányzatokra is.

A rend'szer kialakítása egy-két év alatt megtörténhet. Lényegében a fölkészülésre rendelkezésre áll az 1997-es és az 1998-as év, mivel a jelzett évekre egy három éves program keretében megtörtént az SZJA megosztási játékszabályok rögzítése, s azt felesleges lenne fölborítani. Így megfelelö idö állna rendelkezésre az SZJA pótadóztatásának 1999-töl történö bevezetésére.

Nem javasolt a forgalmi és a vállalati jövedelmi adók pótadóztatása, mert az hosszabb távon rontja a helyi gazdaság versenyképességét. Azt szükséges inkább rögzíteni, hogy az egyes központi adók közül melyik milyen arányban finanszírozza az egyes kormányzati transzfereket. A társasági adó pótadóztatása azért sem javasolt, mert a helyi adók között müködik az iparüzési adó, amely egyfajta helyi forgalmi adóként is múködik. Ennek szerepét azonban hosszabb távon nem növelni, hanem mérsékelni szükséges. Az egyre magasabb kulcsokkal múködö iparüzési adó egyrészt torzítja a helyi vállalkozások versenyképességét, másrészt indokolatlan mértéküvé erösitheti a települések közötti adóversenyt.

A helyi adók közül az ingatlanadó, s azon belül a lakásingatlanok adójának fejlesztése javasolt. Az értékarányos ingatlanadóztatásra való áttérés egyes szükséges elemei megvalósultak (központi mentességek eltörlése), mások megvalósitás alatt vannak (számítógépes ingatlan kataszter, korábbi mentességek 
kifutása, önkormányzati lakásvagyon privatizációja), míg több elem ma is hiányzik (értékelési törvény, képzési programok, lakosság fölkészitése). Az átállás egy négyöt éves idöszakban képzelhető el, amelyben kulcselem a lakosság fölkészitése erre az adótípusra (ezt az SZJA 1988. évi, a jövedelemmel rendelkezők teljes körére kiterjedő bevezetéséhez hasonlatosan kellene bonyolítani). Jelen pillanatban az értékarányos ingatlanadóztatással kapcsolatosan szükséges annak áttekintése, hogy hol tartunk a javasolt folyamatok és a többször leirt stratégiai program lépések megvalósításában.

$\mathrm{Az}$ SZJA hosszabb távon az önkormányzati gazdálkodás egyik alapvető finanszirozási eleme marad. A kilencvenes években az átalakulással lezajló folyamatok (munkanélküliség, illetve gazdasági visszaesés és növekedés területi differenciái), valamint demográfiai okokból, a lakossági jövedelmek területi és települési szintü növekedése prognosztizálható a kővetkezö középtávú idöszakban. Ez továbbra is hangsúlyosan jeleníti meg a jövedelem kiegyenlitési mechanizmus müködtetését az önkormányzati finanszírozás területén.

A kiegyenlitő források rendkívull szétdaraboltan és szétaprózottan jelennek meg a jelenlegi finanszírozási rendszerben. Ennek átalakítása a kővetkezőképpen képzelhető el. A kedvezményezett önkormányzatok nagymértékben átfedik egymást a különbőzö jogcímen megkapott kiegyenlítő támogatások esetében. Célszerủ mindössze két kiegyenlitoó támogatás alkalmazása. Az egyik a müködés pénzügyi feltételeinek kiegyenlítését szolgálná az SZJA kiegyenlító támogatás keretében. A másik pedig a fejlesztéseket segítené a céltámogatási rendszeren keresztül. Mindkét támogatás forrása a központi (vagy központban maradó) SZJA lenne.

Az SZJA összességében négy célt szolgálna. A helyben maradó vagy pótadózott SZJA az összes nettó SZJA 30-40\%-át tenné ki. A központosított vagy központi SZJA pedig fele-fele arányban oszlana meg a kiegyenlítö támogatások és a normatív vagy feladat-orientált támogatások között. Ez utóbbi esetében meg kell határozni azt a hányadot, amelyet a kormányzat nem az SZJA-ból, hanem más adóbevételekböl fedez. A bruttó és a nettó SZJA bevétel közötti kưlönbözet az APEH költségvetésének fedezetéhez járulna hozzá.

$\mathrm{Az}$ államháztartás reformja több ponton is érinti az önkormányzati gazdálkodást. A nagy ellátó rendszerek, így a közoktatás, a szociális ellátás, az egészségügy reformja kihat az önkormányzati feladatokra, az azokra fordítható makroszintü forrásokra, s nem utolsó sorban az elosztási, szabályozási rendszer alakulására is. Ez a normativ támogatási rendszeren keresztül érzékelhetó leginkább az önkormányzatok számára. Szükséges annak eldöntése, hogy milyen irányban fejlesztendö a normatív támogatás rendszere.

Ha a normativitással a forrásszabályozást és a kiegyenlítést egyiüttesen kívánjuk kezelni, akkor elegendö lenne egy négy-öt mutatóból előállított elosztási formulát alkalmazni. $\mathrm{Ha}$ a feladat-orientált finanszirozás kerülne elötérbe, akkor viszont csupán három területre kellene ennek a finanszírozási formának kiterjednie, mégpedig azokra, amelyekben jelentös az állami szerepvállalás is: kőzoktatás, szociális ellátás, egészségügy. Minden más terület - speciális szabályozást igénylö etnikai és nemzetiségi önkormányzatok finanszírozását kivéve - kikerullne a normatív elosztási kulcsok rendszeréből. Azok fedezetét a helyben maradó, vagy helyi SZJA-ból, a helyi bevételekből és a müködést segítő kiegyenlítési rendszereken keresztull kell az egyes önkormányzatoknak elöteremtenie. 
A forrásoldalra nehezedő nyomás csőkkenhet a racionálisabb szolgáltatásszervezéssel. Ez nem jelenti feltétlenül nagyobb önkormányzati egységek kialakításának az erőltetését. A hatékonyabb müködést két folyamat segítheti leginkább. Az egyik az ơnkormányzati feladatok decentralizációja, vagyis a helyi közösségi szolgáltatások egy körében a magánszektor szerepének erösítése. A másik, a közös feladatellátásra, önkormányzati társulások alakításának ösztơnzése. Ezt célszerủbb pénzügyi szabályozással elérni, mint adminisztratív módon, a társulások megalakításának kötelezóvé tételével.

\section{Jegyzetek}

'Ha a fơvárost nem egészében, hanem keruletenként vesszuk számitásba, akkor minden évben Budapest II. kefúlete vezetné a telepulési listát. Az itt képződő egy före jutó SZJA tőbb, mit 5-szơrosen haladja meg a vidéki átlagot.

2 A Világbank 1992-ben készullt ország jelentése a kơltségvetésre és a kơzszolgáltatási szektor mükøodésére osszpontositotta a figyelmét. A jelentés ("A helyi ơnkormányzatok finanszirozása Magyarországon") készítői Richard Bird és Christine Wallich voltak. A munkában a magyar onkormiányzati pénzugyek szakértőjeként Péteri Gábor volt a segitségukre.

${ }^{3} \mathrm{Az}$ IMF Adóugyi Osztályának képviseletében egy négytagú bizottság tett látogatást Budapesten és néhány vidéki telepulésen 1994. augusztus 28. és szeptember 14. kőzơtt. A látogatás célja a magyarországi helyi adók és a helyi ơnkormányzatok pénzügyi rendszereinek reformját segitő technikai segítségnyújtás volt. A bizottság tagja volt: Emil M. Sunley az Adóugyi Osztály igazgatóhelyettese, P. Bernd Spahn az Adóugyi Osztály munkatársa, Robert D. Ebel a Világbanktól, valamint Jorgen Lotz az adóugyi szakértői testủlet tagja. A bizottság munkajat, mint magyar ơnkormányzati finanszírozási szakértói csoport, a budapesti Városkutató Kft. segítette.

4 A javaslatot ("A magyarországi onkormányzati rendszer reformja") a szerzók a Belügyminisztérium folkérésére a brit Know-How Alap keretein belul dolgozták ki 1994-1995-ben.

${ }^{5}$ Az elmúlt idószakban az adókulcs emelések kapesán az emelést ellenzók szivesen hivatkoznak az ún. Laffler-görbére, amely szerint egy meghatározott ponton túl, az adókulcs emelésével már nem növekszik, hanem csőkken az osszes adóbevétel. Ezen vélemények szerint a hazai adótábla felső kulcsai már meghaladták ezt a pontot, ezért a nemzetkơzi osszehasonlításban Magyarországon erőteljesebb az adókơteles jơvedelmek eltitkolása. Nem készulltek azonban publikált elemzések arra, hogy a marginális kulcsok kulơnbőző mértékủ csőkkentésével milyen mértékben változhat az adófizetési morál, s ezáltal akár csókkenő kulcsok mellett is emelkedhetnek az SZJA bevételek. Természetesen az adóbevétel nagyságát nem csupán a kulcsok és az ahhoz kapcsolódó fizetetési hajlandóság határozza meg, hanem az alkalmazott adósávok szélessége, az adóalap- és adócsókkentő tételek tiagyságrendje, valamint az infláció.

${ }^{6}$ Tulajdonképpen az SZJA 100\%-os onkormányzati körben való folosztása nem reális, hiszen ebben az esetben ezt a jơvedelmet nem terheli adminisztrációs kơltség. Ugyanakkor elvárható, hogy az APEH költségvetésének egy részét az SZJA bevétel fedezze. Lehet, hogy igy mükơdik a dolog, de erről nem tudunk, az elszámolás nem nyilvános, nem transzparens.

${ }^{7} \mathrm{Ez}$ a támogatási elem a normatív támogatási rendszer bevezetésekor szuletett. Kozségenkénti ơsszege azóta sem változott: 2 millió Ft minden községi ónkormányzat számára. 1991-ben mintegy 50 onkormányzatnak ez a forrás tette ki a bevételeinek 50\%-át. 1997-re ennek a forrásnak a reálértéke az 1991. évinek az egyơtodére esett.

8 Az 1997. évi kolltségvetést értékelő frások közơtt az önkormányzatok sérelmezték, hogy az ónkormányzati részarány meghatározásánál a kormányzat nem a bruttó, vagyis a teljes SZJA bevételből indult ki, hanem csak a nettó bevételből, vagyis a telepulésekre beazonosítható SZJA bevételekbỏl. Véleményem szerint a nettó SZJA-ból való kiindulás elfogadható akkor, ha látható a "maradék" SZJA sorsa is. Ezt legegyszerübben úgy lehetne transzparenssé tenni, ha ezt a részt az APEH mưkkơdését szolgáló hányadként kezeli a rendszer. Igaz ezek után még mindig kérdés marad, hogy miképpen számolnak el az adóellenơrzések alapján befolyt tơbblet SZJA bevételekkel. 


\section{Irodalom}

Bird R. M. és Wallich C. (1992) Financing Local Government in Hungary. Policy Research Papers. Country Economics Department. The World Bank. March 1992. WPS 869.

Bukki S. (1991) Gyôr önkormányzatának gazdálkodása a városi pénztári iratok tükrében 1867-1876 között. In: Fejezetek a györi ơnkormányzatok tơrténetéböl. In: Györi Tanulmányok 1991/1. Szerk. Lados M. Györ Megyei Jogú Város Polgármesteri Hivatala. Györ. 23-36. o.

Darázs 1. (1997) A '97 évi költségvetési tơrvény ismeretében a lehetőségekröl. ÖN-KOR-KÉP. 1997. január 4-7. 0 .

Davey K. és Péteri G. (1995) A magyarországi önkormányzati adórendszer reformja. (Tervezet). Budapest, Kézirat

Éberth G. (1931) A magyar városok pénzügyi és beruházó tervezete. Györi Hirlap nyomása. Györ

Hegedüs J. - Péteri G. szerk. (1996) Az önkormányzati finanszirozás és gazdálkodás korszerũsítése. FDI-CEE Szeminárium eloaadásai és hozzászolásai. 1996. április 25-26. Budapest

Fehérvári I. (1992) A helyi adók rendszerének müködési tapasztalatai. Adó. Vol. 2. 16-17. o.

Fehérvári l. (1995) A helyi adók - Múködési tapasztalatok. ON-KOR-KÉP. Május-június 12-15. o.

Fehérvári I. (1997) A helyi adó, a gépjármũadó és az illetékbevételek alakulása 1996-ban. Adó. Vol. 6. 49-51. 0.

Illés I. (1994) A vagyon- és ingatlan adózás, mint a terület-és településfejlesztés eszköze. MTA RKK ÉDO, Győr, Kézirat

Illés I. (1996) Az önkormányzati rendszer továbbfejlesztésének fó irányai. In: Az önkormányzati finanszírozás és gazdálkodás korszerüsítése. Szerk.: Hegedüs J. - Péteri G. FDI-CEE szeminárium elóadásai és hozzászólásai. 1996. április 25-26. Budapest, I12-117. o.

IMF (1994) Magyarország: Helyi adók kormányzatközi elszámolások. Budapest, Kézirat

Lados M. (1993/1994) Tax on Immobile Property in the Hungarian Local Government Finance. Rotterdam-Györ, Kandidátusi disszertáció

Lados M. (1995) A helyi adózás és adóigazgatás fejlesztése. A teruleti közigazgatás továbbfejlesztésének irányai és az államháztartás reformja 20. MTA RKK, Pécs-Györ, Kutatási zárójelentés

Lados M. (1997) Pótadóztatás és területi kiegyenlités az önkormányzati finanszirozásban. A területi kőzigazgatás továbbfejlesztésének irányai és az államháztartás reformja 29. MTA RKK. Pécs-Györ, Kutatási zárójelentés

Páll Gy. (1991) Onkormányzati gazdálkodás Györött az 1920-as évek második felében. In: Fejezetek a győri ơnkormányzatok tơrténetéböl. In: Győri Tanulmányok 1991/1. Szerk.: Lados M. Györ Megyei Jogú Város Polgármesteri Hivatala. Györ, 71-93. o.

Pitti Z. (1994) Gondolatok az önkormányzati gazdálkodásról, a vagyonhasznositás kezdeti eredményeirôl, a szabályozórendszer korszerüsítésének lehetséges és kivánatos irányairól. In: Központi-helyi kapcsolatok - Elvek és módszerek. Szerk. Péteri G. Budapest. 95-142. o.

\section{FUTURE PERPECTIVES FOR LOCAL GOVERNMENT FINANCE IN HUNGARY}

\section{MIHÁL Y LADOS}

The paper is making a picture of financial sources, helping Hungarian local governments improving fiscal independence and on the other side, make secure the equalising system amongst settlements with different financial capacities. The first objective belongs to the governmental regulation system, the second has another outer connections too. These sources are using for moderating the differences on income-production through redistribution, or more effective expenditure system in governmental tasks. The other group of equipment use for improving incomeproduction capacity belongs to regional policy. 
The social-economic transformation affected the regions in different ways in Hungary, resulting wider regional differences, than before. This situation came as a result of some dissimilar processes. The governmental infrastructure construction programs moderated the differences. At the same time the leader regions of transition - thanks for the activity of foreign investors - were the traditional more developed areas of the country (Budapest and its agglomeration zone, regional centres, Northwestern Transdanubia).

A real equalising method means, that the local governments - laying in a peripheral area for example - has sources helping for local development. The basis of this method is stabilising sources of current functional expenditures. The desirable situation a certain resource-system, which help the local governments to widen free sources, or on the other hand improve the recent frittered system more effective, transparent and public.

There are two ways in the Hungarian situation, to widen free sources for local governments. The first, change the divided personal income tax (PIT-) system as a local and a centralised part. The second way is developing the value-based property tax system. (In the last few years, we could see the strengthening role of local corporation tax, but in the author's opinion we must weaken the role of this taxation form in longer term, if we'd like a more effective local economy.)

In the local taxation system, the most perspective class is the property-tax group and within this group we should develop the accommodation tax form, based on the value of flats. This change needs at least 4-5 years, similar the introducing of PITsystem in 1988. The nodal point of the process is preparing people for the changes.

The moderating resources are present in the recent financial system, but extremely frittered, squandered way. The potential change should be the following: we should use only two moderating aiding forms of sources. The first, for helping on equalise the current functional expenditures, as a PIT-moderating support and the other for improving local development through an object-aid system. The source of these aids would come from the centralised part of PIT.

It is necessary to upset, how to develop the normative-aid system, too. If we'd like to manage the normative form, together the resource regulation and moderating system, that would be enough to create a simple distribution form, based on 4-5 specimen. If we prefer the object-oriented financing system this form should be concentrated on only three areas (education, social-welfare, health), improving the role of private sector. Any other part - except financing ethnic minorities - would get out of the normative system.

The pressure weight the source side down can reduce with a more rational service organising system. We can improve the more effective functioning in two ways. The first is decentralise functions, the other is stimulate associations of local governments for supplying common functions. This stimulating process based on financial regulation, rather than administrative way. 